Portland State University

PDXScholar

Spring 7-9-2018

\title{
A Mutual Charge: the Shared Mission of Herbert Hoover and Harry S. Truman to Alleviate Global Hunger in a Postwar World
}

Brian Douglas Reese

Portland State University

Follow this and additional works at: https://pdxscholar.library.pdx.edu/open_access_etds

Part of the Political History Commons, and the United States History Commons Let us know how access to this document benefits you.

Recommended Citation

Reese, Brian Douglas, "A Mutual Charge: the Shared Mission of Herbert Hoover and Harry S. Truman to Alleviate Global Hunger in a Postwar World" (2018). Dissertations and Theses. Paper 4478.

https://doi.org/10.15760/etd.6362

This Thesis is brought to you for free and open access. It has been accepted for inclusion in Dissertations and Theses by an authorized administrator of PDXScholar. Please contact us if we can make this document more accessible: pdxscholar@pdx.edu. 


\begin{abstract}
A Mutual Charge:
The Shared Mission of Herbert Hoover and Harry S. Truman
\end{abstract}

To Alleviate Global Hunger in a Postwar World

\author{
by \\ Brian Douglas Reese
}

A thesis submitted in partial fulfillment of the requirements for the degree of

\author{
Master of Arts \\ in \\ History
}

Thesis Committee:

David A. Horowitz, Chair

Joseph Bohling

Chia Yin Hsu

Gerald Sussman

Portland State University

2018 
C 2018 Brian Douglas Reese 


\begin{abstract}
Famine and destitution stemming from the Second World War had spread across the European continent and parts of Asia by mid-1945. Recognizing the need for recovery and survival in those regions, President Harry S. Truman at the recommendation of several Cabinet members, summoned ex-President Herbert Hoover for advice on how the United States should proceed in offering aid beyond the earlier efforts of the United Nations Rehabilitation and Relief Administration and other relief sources. After an absence from the White House and official government participation for many years, Hoover readily provided crucial advice on addressing famine relief in Europe and Asia based on his previous humanitarian leadership during and after the First World War.
\end{abstract}

Recognizing that further action needed to be taken, Truman asked Hoover, as Honorary Chairman of the Famine Emergency Committee (FEC), to go to Europe and Asia to personally assess the famine relief needs. Hoover and several colleagues travelled 50,000 miles to thirty-eight different nations from March and into June 1946 to witness and evaluate famine needs in the afflicted nations, or arrange for food supply resources from various other countries; making a second trip to a struggling Germany and Austria in 1947.

This thesis initially examines the narrative of the period between Hoover's reentry into public service, as requested by Truman, and the chronicle of the FEC missions. At the same time, it considers the purposes of the FEC missions, from both Hoover's and Truman's perspectives, and despite differing political viewpoints, the efforts of the two 
leaders to merge their activities into a common goal. The aim, amid early Cold War challenges, was to encourage both freedom and democracy in Europe and elsewhere, while sustaining free market economies and guarding against the spread of communism. As Hoover focused his efforts on American based humanitarian aid through the mechanism of food relief to promote economic prosperity, stability, and political freedoms, Truman endeavored to protect democracy as expressed in the Truman Doctrine. Both standpoints coalesced in a synthesis of anti-communism, global stability, and U.S. geopolitical interests.

This thesis also will analyze the friendship that developed between Hoover and Truman during the FEC missions. This helped lead to further collaboration between the two leaders, as the President asked the ex-President to assist in the creation of the First Hoover Commission, leading to a Second Hoover Commission under President Dwight D. Eisenhower. Despite ongoing political dissimilarities and occasional disagreements, the friendship of Hoover and Truman strengthened and endured for the remainder of the lives. 


\section{Acknowledgments}

First and foremost I want to thank my Lord and Savior Jesus Christ. For without Him, and His sacrifice and free gift of eternal life, I would be nothing.

I would like to thank my advisor and thesis committee chair, Dr. David A. Horowitz, for his steadfast patience, guidance, knowledge, and time in my research and writing of this work. Thank you as well to Dr. Joseph Bohling and Dr. Chia Yin Hsu of the Portland State History Department, and Dr. Gerald Sussman of the Portland State International \& Global Studies Department for serving on my thesis committee.

To my parents, Jeri and Doug Reese, I give infinite recognition, thanks, and gratefulness for their enduring support and vision, of which I will never be able to repay, during my journey through the Master Degree program and my pursuit of an education. Thank you mom and dad. You are true gifts from God.

I also want to offer my thanks to an extensive list of family members, good friends, and acquaintances who have always encouraged me throughout my time in academia.

I owe a deep debt of gratitude to the entire library staff at the Herbert Hoover Presidential Library and Museum in West Branch, Iowa, Craig Wright, Matthew Schafer, and Spencer Howard, who went above and beyond in their assistance to me during my research there in June 2017. Thank you for making my time there so rewarding, valuable, and memorable. 
...And of course, thank you to President Herbert Clark Hoover and President

Harry S. Truman, for their extraordinary lives and legacies to which this thesis is dedicated. 


\section{Table of Contents}

Abstract..............................................

Acknowledgements..................................ii

Preface............................................. vi

Introduction..........................................

Chapter 1 Two Paths to Collaboration....................10

Chapter 2 Accepting the Charge.........................32

Chapter 3 Into the Mission............................57

Chapter 4 Beyond the Mission........................84

Conclusion..........................................112

Bibliography...................................... 124 
In two wars I served amidst famine. And in the war shattered aftermath I directed reconstruction in many nations. Uppermost in the minds of plain people everywhere was that war should cease and that peace would come the world.

\section{-- Herbert Hoover \\ Presidential Library and Museum Dedication West Branch, Iowa August 10, 1962}

It is my duty to join with the voices of humanity everywhere in behalf of the starving millions of human beings all over the world. We have a high responsibility as Americans to go to their rescue.

-- Harry S. Truman

Radio Address

The White House

April 19, 1946 


\section{Introduction}

Just before 10:30 on the morning of May 28, 1945, Herbert Hoover rode up to the front of the White House in a limousine, ordered by President Harry S. Truman a short time before. The seventy-one year old ex-president quickly strode up the steps, entered the executive mansion, and paced down the hallways towards the oval office, without any pause or words to anyone. ${ }^{1}$ It had been nearly thirteen years since Hoover had been in the White House. Those years had been ones of literal exile from any contact within the previous administration of, the now deceased, Franklin Delano Roosevelt, much less the President himself. A meeting with Truman, the new President, had been developing for over six weeks, and Hoover wasted no time in being prompt for the appointment.

A habit of swiftly facing pertinent business had long been associated with Hoover's renowned character. Truman only knew the elder statesman by name, reputation, and past political histories that saw Hoover as an experienced, though defamed, past President, reproached as a central cause and perpetrator of the Great Depression despite a reputation as a humanitarian leader. Truman, the much lesser defined former Senator from Missouri, had been recently thrust into the U.S. presidency. Nevertheless, coming to know one another would be secondary on this day compared to the looming world famine crisis resulting from the still raging world war.

\footnotetext{
${ }^{1}$ Harry S. Truman interview, October 21, 1959, cited in Robert H. Ferrell, Harry S. Truman (Columbia: University of Missouri Press, 1994), 194.
} 
Having met Truman for the first time that May morning, Hoover would be asked by the President to offer his advice on the food supply situation and pending world famine, with a large focus on Europe. Hoover promptly indicated that not only had the war created the situation, but mismanagement had been a major factor. ${ }^{2}$ Hoover would offer continual advice over the next nine months amid a correspondence with Truman on a variety of political issues.

In late February of the next year, Secretary of Agriculture Clinton P. Anderson would contact Hoover to offer the position of Honorary Chairman of the developing Famine Emergency Committee (FEC) and the opportunity to continue to counsel the President on relief needs. The appointment resulted largely from Hoover's encouraging Anderson to establish a formal relief program and Truman's desire to implement the expresident's experience and advisement. ${ }^{3}$ Led by the United States, the FEC would aim to survey and assess the hunger needs of the war-ravaged populations of Europe and elsewhere, in order to curb and prevent famine from overtaking those peoples and help them recover from the war in the interests of stability and world peace. To accomplish this task Hoover and his assembled team would travel to thirty-eight different countries that included not only nations and peoples affected by the war in Europe and elsewhere, but to countries such as Argentina that might assist in the supply needs of famine relief. The initial segment of the FEC operation and Hoover's involvement would take place in

${ }^{2}$ Herbert Hoover, "Hoover Notes on Meeting With Truman," May 28, 1945, in Herbert Hoover and Harry S. Truman: A Documentary History, ed. Timothy Walch and Dwight M. Miller (Worland: High Plains Publishing Company, 1992), 37.

${ }^{3}$ Notes on a Phone Call From Clinton P. Anderson to Herbert Hoover, February 25, 1946, in Herbert Hoover and Harry S. Truman: A Documentary History, 62. 
the spring of 1946, while a second journey to Germany and Austria resulting from successive poor agricultural harvests in those regions, would occur in 1947.

Hoover's past accomplishments in food relief well qualified him for the assignment. During the First World War, he had served the Woodrow Wilson administration by forming and leading the Committee for Relief to Belgium (CRB), helping the isolated Belgians and Northern French whose food supplies had been impeded by invading German troops, as well as an additional British blockade originally meant to starve the same occupying enemy forces. Some Truman officials had worked with Hoover during his own presidency between 1929 and 1933. Henry Stimson, Truman's first Secretary of War, had served as Secretary of State under Hoover and had been among those that advocated for Hoover's famine relief advice. Stimson found the new President quickly receptive to the idea. ${ }^{4}$ Others like Edgar Rickard, a lifelong confidant and friend of Hoover, would inform him of Stimson's urging for the expresident's assistance. Rickard would record Hoover's desire to help, but not without an invitation from the President himself..$^{5}$ Against the wishes of many others in the administration, Truman would extend the invitation and the meeting would occur.

The President viewed the results of the initial encounter with Hoover as a "most pleasant and satisfactory meeting with him." ${ }^{\prime 6}$ For his part, Hoover would relay his

\footnotetext{
${ }^{4}$ Henry L. Stimson, Diary entry, Harry S. Truman Presidential Museum and Library Archives, May 2, $1945,3$.

${ }^{5}$ Edgar Rickard, Diary entry, Harry S. Truman Presidential Library and Museum Archives, May 13-14, $1945,1$.

${ }^{6}$ Harry S. Truman, Memoirs of Harry S. Truman, Volume One: Year of Decisions (New York: The Da Capo Press, 1955), 309-310.
} 
impression of the meeting in typical business expression revolving around the statistics of the famine relief issue, although admitting that the experience had been productive. In response to Truman's queries he would urge that the War Department immediately take action to organize and begin to alleviate the emergency, a recommendation outlined in a memorandum sent two days later. ${ }^{7}$

The Great Humanitarian, as he had been labeled during his earliest relief work, had been imploring and stressing throughout the Second World War, in several articles, radio addresses, speeches, and memorandums, the need for critical attention to building national food supply rather than military power. Hoover continually advocated that food supply was the key to creating national stability and peace, and that the United States could take the lead in initiating and carrying out such a plan, not only domestically, but in the interests of thousands around the globe. He contrasted America's capabilities and potential with how Fascist Germany and Italy focused their resources on military might to win the war, ultimately resulting in ignoring and starving their own populations. Hoover often warned of the dangers of the "Horsemen of the Apocalypse" which followed modern total war. Famine, Pestilence, Revolution, Unemployment, Suspicion and Hate, as he named them, threatened long-term strength, contentment, and national harmony. ${ }^{8}$

\footnotetext{
${ }^{7}$ Herbert Hoover, "Memorandum for President Truman," An American Epic, Volume IV: The Guns Cease Killing and the Saving of Life from Famine Begins, 1939-1963 (Chicago: Henry Regnery Company, 1964), 105-109.

${ }^{8}$ Herbert Hoover, "We'll Have to Feed the World Again," Collier's Magazine, November 28 and December 5, 1942, In Addresses Upon the American Road: 1941-1945 (New York: D. Van Nostrand Company, Inc., 1946), 269-270.
} 
Hoover had been consistent in this theory since he first entered humanitarian leadership, before and after his term as president. Now again, another opportunity presented itself to serve both his country and others in need. Through this challenge a strong bond and friendship would emerge between Hoover and Truman, that would endure fluctuations of political differences and personal opinions, but improved and persevered to the end of their lives.

It is my goal through this essay to demonstrate the relationship that both presidents established and cultivated, primarily through the involvement and proceedings of the Famine Emergency Committee, and events of the subsequent years that included the First Hoover Commission on government reorganization, and later the Second Hoover Commission. A large component of this true story is how, despite political and personal variations, the friendship and bond between the two leaders sustained itself well into Truman's post-presidential years.

As Hoover once again became engaged in famine relief during his return to public government service, I intend to focus more heavily on his narrative of the events. To a certain extent, this narrative offers a form of redemption of Hoover, rebuilding a reputation beyond one that sees him as the political scapegoat for the coming of the Great Depression of the 1930s. Through his involvement in the FEC, and other humanitarian efforts, Hoover demonstrated how a leader could use his political experience and connections to support humane objectives and service for others rather than using those same endeavors to promote a personal political agenda. 
I will utilize the large amount of primary sources, which include the correspondence and relevant documents between Hoover and Truman before, during, and after the existence of the FEC, along with those relevant to the Hoover Commissions and beyond. Other written and oral history sources from relevant figures, such as the FEC team that accompanied Hoover on his global survey and others connected to the events, add significantly to the objectives of this essay. These sources, found in document collections at the Herbert Hoover Presidential Library and Museum in West Branch, Iowa, and at the Harry S. Truman Presidential Library and Museum in Independence, Missouri, give support to the distinctive friendship and the FEC narrative.

Many of these same documents are available and duplicated in a comprehensive collection assembled by historians Timothy Walch and Dwight M. Miller in Herbert Hoover and Harry S. Truman: A Documentary History (1992), and will be utilized throughout the thesis. Walch, a one-time director of the Herbert Hoover Presidential Library and Museum, and Miller, a Hoover Library senior archivist, have gathered significant and prominent communications and statements by the two Presidents that greatly contribute to the narrative of the bond. Yet both historians indicate that as of 1992, "The story of the extraordinary partnership between Herbert Hoover and Harry S. Truman has yet to be written."

The abundant sources written by Hoover include books such as Addresses Upon the American Road (1946) and An American Epic (1959-1964) that recount and describe

\footnotetext{
${ }^{9}$ Timothy Walsh and Dwight M. Miller ed., Herbert Hoover and Harry S. Truman: A Documentary History (Worland: High Plains Publishing Company, 1992), 271.
} 
his insights and encounters during his service with the FEC and Hoover Commissions, as well as his musings on previous relief work, advisements and political experiences, provide valuable understanding to the task at hand. In addition essays by Hoover such as American Individualism (1922) and The Challenge to Liberty (1934) help to illuminate his nuanced view of the government and assist in comprehending the thoughts and viewpoints that influenced his actions after World War II.

Secondary sources by relevant historians serve as support for biographical and background information on both Hoover and Truman. These include Gary Dean Best, Herbert Hoover: The Postpresidential Years, 1933-1964, Volumes 1\&2 (1983); Richard Norton Smith, An Uncommon Man: The Triumph of Herbert Hoover (1984); Joan Hoff Wilson, Herbert Hoover: Forgotten Progressive( 1975); and Robert H. Ferrell, Harry S. Truman (1994). Although these sources mention the FEC narrative and the Hoover and Truman friendship only briefly, they do focus on political disagreements and contradictions between the two figures, lending important, if only partial perspective, to the story.

Two revisionist interpretations of Hoover are highly insightful. William Appleman Williams's progressive perspective in his essay "What This Country Needs" in Some Presidents: From Wilson to Nixon (1972) places Hoover's passion for American individual opportunity within the context of the former president's fears about the collusion between corporate capitalism and centralized government bureaucracy that he 
saw in New Deal "syndicalism." ${ }^{10}$ George H. Nash, conservative Hoover revisionist and editor of the massive Freedom Betrayed: Herbert Hoover's Secret History of the Second World War and Its Aftermath (2011), helps to communicate Hoover's distaste for militarism as a byproduct of bloated government.

Focusing on the Hoover and Truman's friendship and the FEC story, this thesis spans four chapters. The first provides the biographical background of both figures, giving a basis for understanding the persona of each man, and the influences that shaped them in their earlier years prior and during their entrance and participation in politics. Hoover's former humanitarian work, his preference for food supply as power in contrast to military strength, and his belief in American potential serve as central themes of this section. The initial communications between Hoover and Truman, after FDR's death, serve as a prelude to the official encounter between the two figures.

Chapter two describes the first meeting between Hoover and Truman in May 1945, the discussion about global famine relief needs between the two, and an analysis of the debates and events that lead to the official formation of the FEC and the expresident's Honorary Chairmanship. The examination of this period that proceeds into March of 1946 is critical in understanding how and why the FEC emerged and developed and the influence of world events and relevant individuals, as well as how it broadened the affiliation between Hoover and Truman.

\footnotetext{
${ }^{10}$ William Appleman Williams, "What This Country Needs," Some Presidents: Wilson to Nixon (New York: The New York Review of Books, 1972), 37-42.
} 
The third chapter provides a narrative of the FEC journey to the thirty-eight nations, the first beginning in the spring of 1946, and a repeat trip to Germany and Austria occurring in 1947. This segment not only offers an account of the nations that Hoover and his team visited and surveyed for relief needs and related activities, but depicts the excursions to other nations that potentially could provide assistance in meeting the demand for world food supply. The growing relationship between Hoover and Truman remains an important subtext of the FEC chronicle.

Chapter four describes Hoover's concerns with a developing Congressional relief bill for devastated countries and Truman's other major request to the ex-President to help form the First Hoover Commission on government reorganization in 1947, later continuing as a Second Hoover Commission in 1953 under President Dwight D. Eisenhower. This segment highlights differences of political ideologies between Hoover and Truman regarding Cold War policies amid a friendship that characterizes the remainder of each man's life. After summarizing the previous chapters the Conclusion offers an assessment of the legacy of the Hoover and Truman friendship, the FEC operations, and the Hoover Commissions. To what extent, it asks, did another President and friend bring a degree of redemption to a former president largely discredited by history. 


\section{Chapter 1}

Two Paths to Collaboration

The backgrounds and influences that helped to shape both Herbert Hoover and Harry S. Truman prior to their association possess a degree of similarities and differences. Each man began life in similar areas of the Midwest, with a strong American pioneer heritage that extended several generations before. Their families had strong roots in agriculture, community, and the Christian faith. The education and early career paths of the two later statesmen would diverge, before finally meeting decades later but they shared common experiences in these earlier years.

Herbert Clark Hoover's journey began in the Quaker community of West Branch, Iowa on August 10, 1874. Though orphaned by the age of nine, when his mother Huldah died in 1884 , his father Jesse four years earlier, Hoover had already absorbed strong Quaker roots. ${ }^{1}$ That foundation would be further built upon by his Uncle John Minthorn in Newberg Oregon, who Hoover was sent to live with two years after his mother's death. ${ }^{2}$ Farm work and an office boy job at the Oregon Land Company, both for his Uncle Minthorn, filled much of the remaining years of Hoover's youth. ${ }^{3}$ Graduating in the first class of Stanford University in 1895 with a major in geology, he worked summers for the Geological Survey of Arkansas and assisted the State Geologist before

\footnotetext{
${ }^{1}$ Richard Norton Smith, An Uncommon Man: The Triumph of Herbert Hoover (New York: Simon and Schuster, 1984), 65.

${ }^{2}$ Ibid, 66.

${ }^{3}$ Ibid, 67.
} 
joining the U.S. Geological Survey in California and Nevada. ${ }^{4}$ After serving as a gold mine worker and assistant mining manager in several southwestern states, Hoover took a management position for the British gold mining firm Bewick, Moering and Company in $1897 .^{5}$

With his wife Lou Henry at his side, Hoover traveled across the world for Bewick and Mooring, developing managerial skills and respect for other cultures, in Australia and in China, where he witnessed the Boxer Rebellion, as well as in and Burma and Egypt, and England. He developed a particular appreciation of the patience, tolerance, family values, courage, and work ethic of the Chinese. ${ }^{6}$ Yet Hoover became critical of the stratified British class system, the continued expression of "the white man's burden," and the way "the end justified the means" in regards to "the Empire."”

As a wealthy partner in Bewick, Moering, Hoover yearned to apply his talents to public service. Accordingly, he sought to promote the upcoming Panama-Pacific Exposition in San Francisco while in London in $1914 .{ }^{8}$ When German troops invaded Belgium in August of that year however, Hoover's focus shifted when he was approached by U.S. ambassador in London, Walter Hines Page, to use his managerial talents to assist in the evacuation of 120,000 panicked Americans from the overrun nation. ${ }^{9}$

\footnotetext{
${ }^{4}$ Herbert Hoover, The Memoirs of Herbert Hoover: Years of Adventure, 1874-1920 (New York: The Macmillan Company, 1961), 17.

${ }^{5}$ Hoover, The Memoirs of Herbert Hoover, 1874-1920, 24-28.

${ }^{6}$ Ibid, 66.

${ }^{7}$ Ibid, 75-76,126.

${ }^{8}$ Joan Hoff Wilson, Herbert Hoover: Forgotten Progressive (Prospect Heights: Waveland Press, 1975), 24-25.

${ }^{9}$ Smith, An Uncommon Man, 80.
} 
As the war escalated, Belgian civilians suffered from a lack of food supplies. By October 1914, Hoover and several fellow engineers had organized a food relief project amid the German occupation and a British blockade. He led the Committee for Belgian Relief (CRB) to push 4,500 tons of food supplies through the blockade in an unprecedented relief effort. ${ }^{10}$ Hoover's leadership of the project generated a reputation as a humanitarian and the attention of President Woodrow Wilson who appointed him U.S. Food Administrator through the end of the war. As Food Administrator Hoover urged Americans to boost food production, reduce their own consumption, and deter "wartime profiteering and inflation," in a program based on "voluntary cooperation."11

Leading the American Relief Administration (ARA) after the war, Hoover advocated and managed famine relief in postwar Europe, including Germany, and for those affected by Russia's Bolshevik Revolution. Created by the U.S. Congress at the war's end, and prior to the United State Food Administration, the ARA provided over four million tons of food relief to twenty-three countries affected by the global conflict. Supported by a 100 million dollar budget, the ARA funding doubled with the same amount given in private donations. Hoover's standing as an international business figure and humanitarian subsequently resulted in his appointment as Secretary of Commerce under both Presidents Warren G. Harding and Calvin Coolidge between 1921 and 1928. At the height of national popularity, he was elected President in 1928 in a landslide victory amid the image of an extremely successful "super expert" and sensible "man of

\footnotetext{
${ }^{10}$ Ibid, 81-82.

${ }^{11}$ Smith, An Uncommon Man, 88.
} 
action" able to deal with any obstacles. ${ }^{12}$ Yet the Great Depression unfolded only months into the first year of his term. Unable to reverse the negative economic disaster of the nation and reluctant to authorize a direct system of relief for the needy, Hoover lost his re-election bid in 1932 to Democrat Franklin D. Roosevelt and suffered from a dispiriting decline of status for many years to come.

Like Hoover, Harry S. Truman started out in a small rural community, the farm hamlet of Lamar, Missouri on May 8, 1884. He spent his earliest years on the farm, until the family moved to Independence. ${ }^{13}$ The young Truman suffered from an "unusual sort" of nearsightedness, forcing him to wear thick glasses and refrain from participation in boyhood sports or boisterous play. ${ }^{14}$ In compensation, he took piano lessons once or twice weekly, and from the age of fourteen on practiced two hours each day before heading to school. ${ }^{15}$ Though never attending university, Truman developed a strong fondness for reading, claiming to have read the entire Bible two or three times by the age of twelve, and eventually every book in the Independence library. ${ }^{16}$

Rejected for military service and acceptance at the Military Academy at West Point, Truman briefly attended Spaulding's Commercial College in Kansas City before working on the family farm for his father John and brother Vivian. Between 1903 and 1905 he clerked for two Kansas City banks before a stint with a National Guard artillery

\footnotetext{
${ }^{12}$ Wilson, Forgotten Progressive, 128-129.

${ }^{13}$ Robert H. Ferrell, Harry S. Truman: A Life (Columbia: University of Missouri Press, 1994), 11.

${ }^{14}$ Ibid, 10.

${ }^{15} \mathrm{Ibid}, 15$.

${ }^{16}$ Ferrell, A Life, 19-20.
} 
battery and a return to the farm. ${ }^{17}$ Burdened by the drudgery of farm work, Truman pursued zinc mining and oil refinery investments in Oklahoma without success. ${ }^{18}$ This led to the decision to reenlist in the National Guard in June 1917 once the United States entered World War I, a move inspired by President Woodrow Wilson's wartime principles of a secure peace and international justice as well as his support for Britain and France as allies against the German "barbarians." 19 To his surprise Truman was made first lieutenant of his battery, and later earned the rank of captain as well as a solid reputation for a decisive and frank manner. ${ }^{20} \mathrm{He}$ and his battalion would experience battle in France on the front lines, where he was commended twice for "excellent maintenance of his guns." 21

Upon his return to Missouri in 1919, Truman married longtime acquaintance Bess Wallace and embarked on the partnership of a haberdashery business, which would end in disappointment and a close-out by the spring of 1922 due to lack of sales in a poor national economy. ${ }^{22}$ Thereafter, Truman entered politics, first as a judge in Jackson County. With help from the Pendergast political machine that dominated the Kansas City area, he won election to the U.S. Senate in 1934, and again in $1940 .{ }^{23}$ Truman distinguished himself by heading a committee to investigate the extra percentages, or "padding," paid to contractors building army training camps during the build-up that

\footnotetext{
${ }^{17}$ Alonzo L. Hamby, Man of the People: A Life of Harry S. Truman, (New York: Oxford University Press, 1995), 18-23.

${ }^{18} \mathrm{Ibid}, 48-49,54-55$.

${ }^{19}$ Ibid, 57-58.

${ }^{20}$ Hamby, Man of the People, 67.

${ }^{21}$ Ibid, 78 .

${ }^{22}$ Ibid, 85.

${ }^{23}$ Ferrell, A Life, 92-93.
} 
preceded U.S. entry into World War II. ${ }^{24}$ He subsequently expanded his reputation by investigating the wartime Office of Production Management. On the basis of such standing, President Roosevelt chose the Missouri senator to be his Vice Presidential running mate in the 1944 election, a job that he would retain until forty-six days before his first meeting with Hoover, as President.

On the day Truman succeeded Roosevelt as President, Hoover sent a note of support. "All Americans will wish you strength for your gigantic task. You have the right to call for any service in aid of the country," the former President promised. ${ }^{25}$ Truman knew something of Hoover's management abilities and humanitarian accomplishments. Historian Bruno Cabanes points out that the First World War had inspired transnational standards for the defense of the world's populace affected by the events of the war and the transition from war to peace. ${ }^{26}$ The rights of all levels of humanity and their "wellbeing and moral welfare" were emerging as critical and "self-evident" issues with the onset of the 1920s. ${ }^{27}$ This evolving mindset corresponded to Hoover's desire to use food, a humanitarian staple, as a means of establishing stability and long-term peace.

Historian Nick Cullather cites Hoover's admonition after the First World War that "famine breeds anarchy. Anarchy is infectious, the infections of such a cess-pool will

\footnotetext{
${ }^{24}$ Ibid, 156.

${ }^{25}$ Herbert Hoover to Harry S. Truman, April 12, 1945, in Herbert Hoover and Harry S. Truman: A Documentary History, ed. Timothy Walch and Dwight M. Miller (Worland: High Plains Publishing, 1992), 28.

${ }^{26}$ Bruno Cabanes, The Great War and the Origins of Humanitarianism: 1918-1924 (New York: Cambridge University Press, 2014), 17, 5.

${ }^{27}$ Ibid, 6
} 
jeopardize France and, Britain, [and] will yet spread to the United States." ${ }^{28}$ Cullather describes Hoover's view that hunger and unemployment "will not be cured at all by law or by legalistic processes," or by Bolshevism, as he had stated at the onset of famine in Russia in 1921. Hoover's belief that the United States could help alleviate war by example and ideology, mirrored his conviction that similar programs could come about through enhancements in the "standards of living.".29

Other significant humanitarian figures of the postwar World War I period, such as Fridtjof Nansen, René Cassin, and Eglantyne Jebb embraced the concept of transitional rights and the need for international institutions and the networks of experts that sustained them. Hoover and Nansen, for example, worked together during the relief of the famine stricken population of revolutionary Russia between 1921 and $1923 .^{30}$ As an American philanthropist and businessman, Cabanes points out, the former mining engineer had indeed organized the two biggest humanitarian operations of the twentieth century, the first being in Belgium and the second only a few years later in Russia. ${ }^{31}$

Cabanes asserts that without considering the Quaker roots Hoover gained in his early life it would be difficult to comprehend the moral core of the Committee for Belgian Relief. ${ }^{32}$ The Quakers, or as Hoover points out in his Memoirs, "more properly the 'Friends'," practiced lengthy hours of somber waiting in the meeting-house for a

\footnotetext{
${ }^{28}$ Nick Cullather, The Hungry World: America's Cold War Battle Against Poverty in Asia (Cambridge: Harvard University Press, 2010), 22.

${ }^{29}$ Cullather, The Hungry World, 22-23.

${ }^{30}$ Cabanes, The Great War, 17.

${ }^{31}$ Cabanes, The Great War, 15.

${ }^{32}$ Ibid, 17.
} 
member to be moved by the spirit. Hoover affirms that the practice would instill a focus on patience. ${ }^{33}$ Other qualities included the worthiness of labor, individual responsibility, practicality, not forming class distinctions, and service to neighbors, along with an obligated response to express shared brotherhood. ${ }^{34}$ West Branch itself, though strongly resembling other Midwestern towns, seemed to have a particular sense of practical, unsophisticated solidity that coincided with the pious nature of Quaker virtues of strict morality. At the same time Quakerism nurtured the benefits of intellect and culture and attention to the issues of the outside world, demonstrated by the town's provision of both public and private schools. Just as the Friends held to the theology of the "Inner Light" of unseen decency, rationality, and an accord within the world, Quakers saw themselves as significant participants in that same world. ${ }^{35}$ For example, West Branch served as a stop along the Underground Railroad before the Civil War and supported black suffrage in 1857 and 1868 referendums (one of only nine precincts in Iowa to do so), while local Friends assisted former slaves by steering them to areas where they could prosper and own homes long after the war. ${ }^{36}$

The same concepts of harmony and voluntary cooperation emerged in what Hoover would later label as "progressive individualism." 37 Decades later Hoover would say to friends "I was a Quaker, but I did not work very hard at it," alluding to the difficulty in finding enjoyment as a child within the denomination's rigidity. ${ }^{38}$ Yet he

\footnotetext{
${ }^{33}$ Hoover, The Memoirs of Herbert Hoover: 1874-1920, 17.

${ }^{34}$ Smith, An Uncommon Man, 61.

${ }^{35}$ David Burner, Hebert Hoover: A Public Life (New York: Alfred A. Knopf, 1979), 7-8.

${ }^{36}$ Burner, A Public Life, 8.

${ }^{37}$ Wilson, Forgotten Progressive, 6.

${ }^{38}$ Smith, An Uncommon Man, 65.
} 
would adhere to Quaker righteousness in his private and public business grounded on a cooperative work ethic in which all community members focused upon doing all that they could within their own "callings" for the benefit of all. ${ }^{39}$ This same cooperation and aim for achievement also called for leadership that could offer skilled direction and management that exemplified social responsibility. ${ }^{40}$

Hoover's upbringing and World War I experiences fostered a form of individualism that rejected unchecked social irresponsibility but called for an "ordered liberty" that would create a balance between the individual and society. ${ }^{41}$ Hoover summarized these ideas in American Individualism, published in 1922. Untampered and rampant individualism, he acknowledges, would lead to discrimination, oppression, and moral wrongs. In contrast, he argues, America had "tempered the whole conception of individualism by the injection of a definite principle," and through this principle any attempt to dominate industry and economy could be restrained. The "values of individualism," Hoover suggested, with their inspiration to "initiative, to the development of hand and intellect, to the high development of thought and spirituality," must be toughened and strengthened with the solid, constant "ideal of American individualism-an equality of opportunity." 42

Within this context, Hoover warned of the potential danger of radical social forces who saw themselves as the only expression of liberalism by advocating human

\footnotetext{
${ }^{39}$ Wilson, Forgotten Progressive, 6.

${ }^{40}$ Ibid, 7.

${ }^{41}$ Ibid, 7.

${ }^{42}$ Herbert Hoover, American Individualism (West Branch: Herbert Hoover Presidential Library Association, Inc., 1922), 34.
} 
advancement via the government. An even larger menace would emerge from destructive criticism which can undermine a society and its optimism, he asserted. As evidence, he pointed to the decline of past civilizations as the result of "wrong ideas," and noted that the world war also had been fought by promoters of conflicting social philosophies. ${ }^{43}$

"The primary safeguard of American individualism is an understanding of it;" Hoover stated, "of faith that it is the most precious possession of American civilization, and a willingness courageously to test every process of national life upon the touchstone of this basic social premise." 44 The idea of individualism could be seen as a form of American Exceptionalism, a belief that America holds the unique position to save the world. Yet Hoover is not making the case for endowing America with a superiority over the rest of humankind. This difference can be evidenced in the perspectives of his Memoirs. As a mining engineer in China, Hoover referred to the "sheer loyalty" of his household helper Quah, during the Boxer Rebellion, and noted how the Chinese would always honor a contract, and demonstrate the greatest integrity. Hoover points out that "commercial law" was a rare if not a newer concept in China since the Chinese still conducted diligent commercial practices and were met by social ostracism if agreements were not met. Simultaneously, Hoover asserts that as in all races elements of bad individuals existed in China, yet the "relative proportions of good and bad there depends a great deal on how much they have to eat." He adds his doubts that Americans would function as the Chinese did with a similarly limited supply. ${ }^{45}$

\footnotetext{
${ }^{43}$ Ibid, 60-61.

${ }^{44}$ Ibid, 61.

${ }^{45}$ Hoover, The Memoirs of Herbert Hoover:1874-1920, 63.
} 
Hoover's memoir, however, draws a clear distinction between American and British society. He points out that the United States had never fostered the class divisions as did Britain, or the "impenetrable stratifications" that induced the desolation of the lower classes. Hoover also asserts that America was a great distance ahead in the sphere of "essential social actions" such as free public education uninhibited from upper class sanction, as well as with laws that regulated monopolies and unrestrained trade. ${ }^{46}$

Hoover's subsequent role as wartime Food Administrator anticipated the social virtues outlined in American Individualism. "Food Will Win The War" became a popular slogan in America, a representation of the idea of everyone willingly in cooperation with the efforts to conserve food intake and resource management. Through the "agency of public exhortation," Hoover hoped to instill American citizens with the ethic of volunteerism he saw as central to national character. ${ }^{47}$

As Food Administrator Hoover quietly oversaw U.S. food intake, production, and output. ${ }^{48}$ Regulations included fixed price controls to avert uncontrolled speculation, but the Food Administration also encouraged Americans to observe and implement meatless and wheatless days each week and to bake "victory" bread with fifty percent wheat. ${ }^{49}$ Hoover also campaigned for "decency in feeding Europe," on the expediency of averting the war from potentially reaching the U.S. east coast, and helping the citizen to engage with the war effort. ${ }^{50}$ Hoover's time in Belgium also can be viewed as an engineering

\footnotetext{
${ }^{46}$ Ibid, 127.

${ }^{47}$ Burner, A Public Life, 102.

${ }^{48}$ Ibid, $110-111$.

${ }^{49}$ Ibid, 102, 105.

${ }^{50}$ Burner, A Public Life, 102-103.
} 
endeavor that incorporated the social values built on volunteerism and cooperation. Along with his Quaker background, the experience pushed him towards using relief as the most tangible and evident answer to tragedy and misfortune, utilizing the Food Administration's "moralistic and hortatory" qualities to demonstrate the manner in which a society should handle an emergency. ${ }^{51}$

With his scientific and efficiency methods towards managing food relief and related social issues, Hoover demonstrated his place as a progressive of the early twentieth century. Self-sufficiency, he believed upon returning to the United States at the end of the war, was the key to nearly limitless economic growth, separate from foreign dependency. Yet the primary issue by the war's end became the safeguarding of world peace, which would instigate Hoover's appeal for international economic cooperation on the reconstruction of a ravaged Europe. ${ }^{52}$

For the one-time Food Administrator, this meant the application of "associational corporatism," cooperation between private and public sectors of the political economy. Yet the principle became compromised and obscured during the 1920s by the rise of monopolies and oligarchic economic methods and was later discarded by the onset of the Great Depression in lieu of a liberal welfare state. The principles of the Associative State stemmed from the scientific management ideas of Fredrick Winslow Taylor. All social activities and institutions could be affected by the cultivation of industrial efficiency techniques, Taylor believed. This appealed to Hoover, who agreed with Taylor's

\footnotetext{
${ }^{51}$ Ibid, 111-112.

${ }^{52}$ Wilson, Forgotten Progressive, 65.
} 
engineering approach to the use of statistical analysis and the cause-and-effect relationship, as well as the theory that any shared interests between employee and employer were disappearing through monopolies but could be solved by a significant movement and change towards the use of scientific engineering. ${ }^{53}$

After serving over seven years as Secretary of Commerce, Hoover had become a popular figure in the business community and across the nation, which greatly assisted his election to the presidency. Yet he loathed typical political clamor and delivered his speeches in a monotone, uninspiring manner with a statistical focus, a pattern that continued once he won the election. ${ }^{54}$ But as historian William Appleman Williams indicates, Hoover was distressed that Americans did not grasp the full scope of cooperative action and "take charge of their immediate lives," thereby jeopardizing their futures by averting their obligations and potentially accepting a diminished outcome. Hoover believed, Williams asserts, that it was necessary for people to save their own country, "or it does not get saved." 55

Williams argues that Hoover feared that the direct involvement of the governmental system within people's lives would cause the independent dream to die, leading government to rule them instead of serving them. ${ }^{56}$ Yet the President's inability to address massive suffering as Depression economic activity fell to half its former strength and unemployment soared to twenty-five percent destroyed any chance of

\footnotetext{
${ }^{53}$ Ibid, 39.

${ }^{54}$ Ibid, 127.

${ }^{55}$ William Appleman Williams, "What This Country Needs," Some Presidents: From Wilson to Nixon (New York: The New York Review of Books, 1972), 39.

${ }^{56}$ Ibid, 36-37.
} 
reelection in 1932 and ushered in the New Deal and Franklin D. Roosevelt. During the immediate post-presidential years, Hoover became especially dissatisfied with the direction of Roosevelt's New Deal, a series of federally sponsored financial reforms, regulations, and social welfare programs designed to spur recovery and stabilize the economy. His fear of governmental control would emerge in the highly critical The Challenge to Liberty (1934).

Hoover asserted that "True American Liberalism" did not exist as a network of static procedures, but was progressive in nature because it stimulated growth. ${ }^{57}$ Aligning with the views he had espoused in American Individualism, he warned that excessive government authority had threatened the concept of freedom not only in the United States but across the globe. He attributed this to the attempt to regulate the widespread social influences resulting from political and economic disruptions such as the First World War and to massive advances in technology. Nevertheless, he cautioned, power-hungry individuals and governments were heedlessly hurting and often extinguishing "fundamental human liberties" that had existed for centuries. ${ }^{58}$

Hoover argued that New Deal regimentation posed a large part of the threat to "true American Liberalism." The immense centralization of power within the Executive branch without the necessary consent of Congress emerged as a major element of Hoover's criticism. ${ }^{59}$ The implementing of government codes that "limited real

\footnotetext{
${ }^{57}$ Herbert Hoover, The Challenge to Liberty (West Branch: Herbert Hoover Presidential Library Association, Inc., 1934), 83.

${ }^{58}$ Ibid, 65.

${ }^{59}$ Ibid, $122-125$.
} 
competition" within commerce and industry alongside the planned entrance of "the government into business in competition with the citizen, or in replacement of private enterprise," he suggested, resulted in the "regimentation of the people directly into a bureaucracy," and the ultimate danger to individual freedoms. ${ }^{60}$ Hoover continued to express these concerns throughout the remainder of the 1930s and into the Second World War.

As the war erupted in Europe and the Pacific, Hoover did not retreat from his insistence on the value of food supply as power and the ability of American principles, ideals, and capabilities to avert further calamity. Though he had been out of office since 1933 Hoover remained active in his attention to world events, and pushed his theories of food supply and relief in the public forum. In a 1942 Collier's Magazine article Hoover demonstrates a foreshadowing of his postwar relief plans. "A starving world must be fed after this war ends" he begins his commentary, respectfully repeating a promise that had repeatedly been made by Allied leaders. Hoover asserts that the victims of war would have to be fed to maintain a lasting peace, unless America would be willing to see millions of people die "after we have made gigantic sacrifices to give them a chance to live."

Though late in 1942 the war's future was uncertain, Hoover reveals a confidence that the United States and its Allies will indeed win the war, an allusion to his conviction of American capacities. At the same time he warns of the problems that would arise with hunger needs in the devastated nations, requiring preparedness and a renewed approach

${ }^{60} \mathrm{Ibid}, 126-132$. 
within American agriculture. Hoover also alludes to the need to cooperate with sources of supply from South America and reach agreements with U.S. Allies about global supplies, finances, shipping, management, and organization on a massive scale. ${ }^{61}$

Hoover refers to the Horsemen of the Apocalypse - Famine, Pestilence, Revolution, Unemployment, Suspicion, and Hate - as the results of modern warfare. He asserts that 148 million people within occupied democracies were already suffering, with millions starving. Hoover indicates that the Nazi's food supplies would be made sufficient for their war aims, due to the massive prisoner work force, but because of the war focus were severely depleting their resources of manpower and materials ${ }^{62}$ Recalling what America accomplished in helping to feed a destroyed Europe at the time of the First World War Armistice in 1918, Hoover asserted that the United States would only be capable of meeting less than half of the hunger needs of the starving countries at the time he wrote the article in 1942. Ending the war as Germany might, with no supplies to sustain itself, had to be averted in America, Hoover warned, supporting his view with a typical presentation of statistics regarding the potential for proper management of existing resources on the home front. ${ }^{63}$

Hoover would continue offering opinions on the American food supply through numerous articles and speeches given across the United States through most of the war. Appealing to the Conference of Mid-West Governors in the spring of 1943, Hoover

\footnotetext{
${ }^{61}$ Herbert Hoover, "We'll Have to Feed the World Again," Collier's Magazine, November 28 and December 5, 1942, in Addresses Upon the American Road: World War II, 1941-1945 (New York: D. Van Nostrand Company, Inc., 1946), 269.

${ }^{62}$ Ibid, 270.

${ }^{63}$ Ibid, 292-294.
} 
repeated that food supply was critical to not only feed Americans but to build strength and avoid anarchy once the war ended ${ }^{64}$ In an address to the Senate Committee on Appropriations earlier that year, Hoover had warned of potential strains affecting the home front that would affect the ability for ultimate victory. Insisting on the need to increase the production of meats and fats, despite a looming decrease in the same supplies, he insisted that support of food production was crucial to avoid an overseas post-war famine and threaten world peace. Agriculture was the most important factor beyond military machinery, he declared. ${ }^{65}$

The war had yet to be won by the Allies when Truman took the oath of office on April 12, 1945. The new president entered the office inexperienced in diplomacy in the face of a tentative global future and uncertain Russian relations. Nor had he been well informed of the sophisticated planning that had occurred among the top officials of the State, War, Navy, and Treasury departments, in addition to the Joint Chiefs of Staff. Truman would initially approach these challenges with a general understanding of history and an intuitive grasp of past experience, while simultaneously mixing a narrow approach to nationalism with "pragmatic internationalism."66

At the same time, as Truman entered the White House he was confronted by an administration at odds with itself and in apparent disorganization. The size of the federal

\footnotetext{
${ }^{64}$ Herbert Hoover, "Our Food Front," Speech at Conference of Mid-West Governors, March 15, 1943, in Addresses Upon the American Road: World War II, 1941-1945 (New York: D. Van Nostrand Company, Inc., 1946), 331-332.

${ }^{65}$ Herbert Hoover, "Food Production, Manpower, Machinery," Address to Senate Committee on Appropriations, Washington D.C., February 8, 1943, in Addresses Upon the American Road: World War II, 1941-1945 (New York: D. Van Nostrand Company, Inc., 1946), 196-197.

${ }^{66}$ Melvyn P. Leffler, A Preponderance of Power: National Security, the Truman Administration, and the Cold War (Stanford: Stanford University Press, 1992), 26.
} 
bureaucracy had greatly increased during Roosevelt's administration, with the now deceased President acting as a "hub," making him the central organizer attempting to control the extended tangle. This had included a cabinet that, as Truman thought, had been filled with the appointment of inept and self-centered figures. He realized that he had to reverse a counter-productive bureaucracy and elicit his own administrative skills to undertake needed changes. ${ }^{67}$

"No one who had not had the responsibility can really understand what it is like to be President, not even his closest aides or members of his immediate family." Truman would recount in his memoirs. "What kept me going in 1945 was my belief that there is far more good than evil in men and that it is the business of government to make the good prevail." Not being one to make quick decisions, Truman related, would force him to gather all the necessary and obtainable facts and information to help form decisions and not be concerned about them later. ${ }^{68}$

As Hoover wished the new President "strength for your gigantic task" the same day Truman took office, he offered the assurance that "You have the right to call for any service in aid of the country." ${ }^{\text {" }}$ Though a traditional gesture of cordiality, the message indicates Hoover's familiarity with the job and position Truman faced, along with the brief comment on his own availability, or hope for opportunity of service. Two days later Hoover expressed optimism about Truman to friend Edgar Rickard, pointing out that

\footnotetext{
${ }^{67}$ Ferrell, Harry S. Truman, 184-185.

${ }^{68}$ Harry S. Truman, Memoirs of Harry S. Truman, 1946-1952: Years of Trial and Hope, Volume II (New York: Da Capo Press, Inc., 1956), 1.

${ }^{69}$ Herbert Hoover to Harry S. Truman, April 12, 1945, in A Documentary History, 28.
} 
Cabinet selections were of immediate importance. Simultaneously, Hoover voiced a desire to be named as the Secretary of War, with the intention of using the nation's shipping to provide relief to Europe as soon as possible. ${ }^{70} \mathrm{With}$ no suggestion of a Cabinet posting, Truman replied just as graciously five days later saying that the "good wishes are deeply appreciated," while also adding in the postscript that "I assure you I shall feel free to call upon you. Thanks for the offer.",71

Henry L. Stimson, once Hoover's secretary of state and now Truman's secretary of war, enthusiastically pressed for the advice of the ex-president regarding the massive global food deficits that he and other administration members knew would exist after the war. Stimson became the strongest advocate within Truman's circle for Hoover's assistance, well aware of his abilities. He would approach Truman on both May 2 and 4, learning that the President had been thinking about the idea himself. When Stimson stressed that Hoover should not be placed in an official executive position but rather used for general advice, the President politely agreed. ${ }^{72}$ Financier Bernard Baruch and several friends appealed to Hoover on May 6 to personally approach Truman to offer advice on the looming famine problem. Yet Hoover reminded the group that he would not see Truman unless asked to do so by a direct invitation from the President himself. When Baruch and the others indicated that Truman genuinely sought Hoover's advice, Hoover remained adamant that it would require Truman's personal invitation for a meeting. Hoover felt as well that if he went to Washington without that direct request it would

\footnotetext{
${ }^{70}$ Diary of Edgar Rickard, April 14, 1945, in A Documentary History, 28.

71 Truman to Hoover, April 19, 1945, in A Documentary History, 29.

72 Henry L. Stimson, Diary entry, May 2, 1945, in A Documentary History, 29-30.
} 
only appear as an effort to avoid upsetting the "left-wingers," or those in the Democratic party "by putting the onus of the visit" on him. ${ }^{73}$

Stimson would continue during the next few weeks to lead in urging Hoover to take the step to call upon Truman and offer his help. Yet when Stimson and Hoover met for lunch on May 13, Hoover continued to want Truman to take the first action. He said that the New Deal had pictured him as "the goat in campaigns," and reiterated that Truman must take the initiative if he wanted any cooperation. Despite efforts and a continued persuasion, Stimson could not get Hoover to move first, even in light of Truman's agreement with the ex-president's public suggestion of the U.S. army taking charge of European relief.

Rickard indicated Hoover's assessment of Truman, somewhat through what he gathered from Stimson, as a positive administrator, available and open to those around him. This, Rickard asserted, had been in large contrast to F.D.R. who would not be accessible for any discussion for weeks at a time. Yet Rickard equally concurred with his friend Hoover of not falling into the snare of being the first to initiate the first meeting with the President. ${ }^{74}$

Stimson continued his pursuit even as Hoover admitted to his one-time cabinet member that he had been stubborn before in other cases and this time he would be persistent again. Under no circumstances would Hoover go to Washington and meet with

\footnotetext{
${ }^{73}$ Herbert Hoover, Hoover Notes of Meeting with Bernard Baruch, May 6, 1945, in A Documentary History, 30-31.

${ }^{74}$ Edgar Rickard, Diary entry, May 13-14, 1945, in A Documentary History, 32-33.
} 
Truman unless asked by the President, initiating more frustration from Stimson. At the same time, Hoover heard that members of the "left-wingers," as he would label Truman Democratic aides and staffers like White House Press Secretary Steve Early, were making comments about his needing to beg the President to participate in the famine emergency coordination. In response, Hoover indicates that "if Truman did not think it worthwhile to pay this small courtesy to me for the benefit of my advice, they had better not continue to attempt it." 75

Truman had revealed his interest and willingness to discuss the famine situation in Europe to Stimson and others who supported the idea. Yet the President knew just as well that there were members of his staff, like Early who did not advocate for Hoover's help. Aware as well of Hoover's strong reluctance to initiate any meeting, Truman finally wrote a letter in longhand inviting Hoover to come to the White House for a meeting. He averted his aides and put the letter in the mail himself on May 24. He would disclose the move to his aides the next day, humbly imparting that his aides "might all throw bricks at him," but it had been a decision he had made after studying the food situation in Europe. Early was indeed troubled, saying that Hoover had never come to the White House during F.D.R.'s presidency to pay his respects, and that he had made attempts for the expresident to visit without success. ${ }^{76}$

\footnotetext{
${ }^{75}$ Herbert Hoover, Hoover Notes of Phone Call With Henry L. Stimson, May 17, 1945, in A Documentary History, 33-34.

${ }^{76}$ Eben A. Ayers, Diary entry, May 24, 1945, in Herbert Hoover and Harry S. Truman: A Documentary History, 35.
} 
Truman began his note with a respectful "My dear Mr. President:-," and continued with "If you should be in Washington, I would be most happy to talk over the European food situation with you. Also it would be a pleasure to me to become acquainted with you. Most sincerely HARRY S. TRUMAN." 77

Truman had made his own decision to contact Hoover against the wishes of certain aides, but the action demonstrated his personal initiative that the new President had, and what he perceived as valuable in others. The gesture of respect, and desire to learn from Hoover's experience had been apparent in the note, as was the President's hope to get to know Hoover first hand. Taking this first step would end Hoover's more than twelve years of separation from the White House, and begin both the planning stages of what would become the Famine Emergency Committee and an emerging friendship between the two leaders.

\footnotetext{
${ }^{77}$ Harry S. Truman to Herbert Hoover, May 24, 1945, in Herbert Hoover and Harry S. Truman: A Documentary History, 35.
} 


\section{Chapter 2}

Accepting the Charge

Just as ex-President had sent his message of good will to the new President a month and a half earlier, another wheel was set into motion once Truman had slipped his note into the mail. Hoover responded two days later to Truman's requisite invitation to meet at the White House and discuss the volatile and known food insufficiency in postwar Europe. The reply was written longhand, just as Truman's note had been, and one of only two known handwritten communications between the two men as indicated by historians Timothy Walch and Dwight Miller. ${ }^{1}$ It was a simple and positive affirmation from Hoover towards the initial meeting and to Truman's apparent cordiality, the personally authored notes demonstrating a sign of respect and reciprocated connection. "Dear Mr. President. I have your most kind invitation of the $24^{\text {th }}-$," Hoover wrote, "I will be glad to come to Washington anytime your convenience and I am asking one of your secretaries to fix an hour- Yours Sincerely, HERBERT HOOVER"2

The invitation from Truman had delighted Hoover, Edgar Rickard denoted. Hoover spent the afternoon of May 27 at his Waldorf Astoria Hotel suite in New York City, actively gathering any pertinent material that he felt necessary to provide the President, in the case that Truman would require "real help." He was uncertain, at this

\footnotetext{
${ }^{1}$ Timothy Walch and Dwight M. Miller ed., Herbert Hoover and Harry S. Truman: A Documentary History (Worland: High Plains Publishing Company, 1992), 36.

${ }^{2}$ Herbert Hoover, Letter form Herbert Hoover to Harry S. Truman, May 26, 1945, A Documentary History, 36.
} 
point, about accepting the job with the current Administration, apprehensive about what the potential results of the meeting happening the next day, yet obviously excited about having the opportunity to impart advice and be able perhaps to gain public acknowledgement of his ability. Having lunch with Bernard Baruch earlier that day, hoping for any necessary support, Hoover related to the financier and former President Franklin Roosevelt advisor what he anticipated conveying to Truman. ${ }^{3}$

In a 1959 interview, Truman recalled telephoning Hoover in Washington D.C. on the morning of the $28^{\text {th }}$ to inform him of the limousine already in route to pick him up to bring him to his "old home." Truman started the call saying "Hello, Mr. President." Hoover not recognizing the President asked "Who is this?" Truman simply responded "Harry Truman," before enlightening his guest of the approaching transportation. Truman recollected the arrival of Hoover and his entrance into the White House as straightforward and swift, passing by the President's daughter Margaret Truman who inquired about the identity of the "tall man" to an older usher who easily recognized the ex-President. $^{4}$

An account offered by Truman historian Robert Ferrell of the first meeting between Hoover and Truman in the oval office at 10:00 a.m. on May 28, depicts that the President asked the Great Humanitarian about examining the world food supply situation. Yet Hoover immediately stood up and walked out of the room without uttering a word, to the bewilderment and offense of Truman who turned to the others in the room, Secretary

\footnotetext{
${ }^{3}$ Edgar Rickard, Diary entry, May 26-27, 1945, in A Documentary History, 36.

${ }^{4}$ Harry S. Truman interview, October 21, 1959, cited in Robert Ferrell, Harry S. Truman (Columbia: University of Missouri Press, 1994), 194.
} 
of State James F. Byrnes and Secretary of Agriculture Clinton P. Anderson, for a possible explanation. Anderson voiced a rationalization to Truman saying “Don't you realize, the man couldn't answer. There were tears in his eyes and couldn't speak," testifying to the depth of Hoover's appreciation of being called upon for service after so many years of feeling overlooked. The account maintains that Hoover telephoned Truman twenty minutes after walking out to accept the charge of advising and surveying the world food supply and clarifying the loss of composure by saying "Because, Mr. President, since 1932 no one has asked me to do anything for my country. You are the first one."5 Different than Ferrell's secondary account, Truman's recollection of this meeting, as described in his Memoirs is not as elaborate but indicates the first experience with Hoover to be a "most pleasant and satisfactory meeting with him."6

Giving no indication as to any emotion in regards to meeting the President, Hoover compiled a summary of the conversation that entailed not only providing preliminary advice on world famine issues, but also his perspective on the domestic food situation. He indicates an earlier recognition and opinion of Truman as someone who advocated relief activities during his time as Senator. Hoover also acknowledged that a positive change had occurred in his own outlook for the assistance of starving people of the world upon Truman's ascendancy to the presidency. By that time in 1945, Hoover points out, the communists had taken over Romania, Hungary, and Albania while the United Nations Relief and Rehabilitation Administration (UNRRA) was "barely present

\footnotetext{
${ }^{5}$ Robert Ferrell, Harry S. Truman (Columbia: University of Missouri Press, 1994), 194-195.

${ }^{6}$ Harry S. Truman, Memoirs by Harry S. Truman, Volume One: Year of Decisions (Garden City: Doubleday \& Company, Inc., 1955), 309-310.
} 
in Western Europe" with the exception of Greece and Italy, but instead focused its strengths on Eastern Europe. Hoover also asserted that although the Allied armies were in the liberated nations of Western and Eastern Europe once occupied by the Axis power of Nazi Germany or Fascist Italy, their efforts were ineffective. ${ }^{7}$

Approximately three weeks before the White House meeting, another gathering between Hoover and colleagues at Carnegie Hall, New York City took place to listen to the account of the Bishop of Chichester. As a prominent British prelate he described the desperate food situation he had witnessed among the civilians of liberated countries, particularly affecting the growth and development of children. Additional and similar accounts had come from Archbishop Cardinal Spellman who had observed destitution in France, Belgium, and Italy. Hoover used a May 16 radio broadcast to clarify his declaration a week earlier that the U.S. Army should assume control of food relief in the liberated nations of Western Europe. Although he believed that the army had the necessary administrative, personnel, and transportation resources, however, he pointed out that the three and one half million men of the armed forces should not assume responsibility for all relief operations. Nevertheless, Hoover signified that the first meeting with Truman symbolized an additional and real opportunity towards pursuing relief. $^{8}$

During the May $28^{\text {th }}$ meeting Hoover stressed the necessity of utilizing the military to assume the immediate emergency relief action in the liberated European

\footnotetext{
${ }^{7}$ Herbert Hoover, "The Relief Scene Shifts," An American Epic: The Guns Cease Killing and the Saving of Life from Famine Begins, 1939-1963, Volume IV (Chicago: Henry Regnery Company, 1964), 101.

${ }^{8}$ Ibid, 102-104
} 
countries. In a later assessment in An American Epic, Volume IV (1964), Hoover indicates that as a result of Truman's immediate action, based on this recommendation and others, approximately three million tons of food had been supplied to these affected regions between June and August of 1945. But he pointed out to Truman, during the first White House meeting, the absence of a sustained and controlled overseas relief effort, since the initial liberation of Western European countries coincided with an inadequate harvest in 1944 , leading to a problem that had to be solved for the sake of any future stability and a potential "embarrassment" for the Allied armies. ${ }^{9}$

The UNRRA organization efforts had also been inept and helpless from their inception, Hoover advised Truman. He criticized "the dominance of power politics and lack of authority" as the primary reasons for its inability to address the serious economic issues that were plaguing Europe. He also specified the need to approach the affected population of Europe as three different areas. This consisted of the recent Soviet realm of over 170 million people; Northwestern Europe comprised of France, Belgium, Holland, Denmark, Norway, and the area of Germany now occupied by the Allies; and the Mediterranean region made up of Italy, Greece, and several smaller nations. At the same time Hoover felt that assisting the Soviet population at that time was not effectively possible without sufficient information regarding their condition. Instead, he suggested the efforts for Northwestern Europe and the Mediterranean be managed in two phases: an

\footnotetext{
${ }^{9}$ Herbert Hoover, "President Truman Requests My Assistance," American Epic: The Guns Cease Killing and the Saving of Life from Famine Begins, 1939-1963, Volume IV (Chicago: Henry Regnery Company, 1964), 105-106.
} 
immediate emergency stage until the coming harvest of August 1945 and the longer stage accompanying the harvest of the next year. ${ }^{10}$

Hoover noted that as long as the populations of the affected European countries would be able to survive for ninety days, time remained to develop a planned approach. The immediate relief of Northwestern Europe, he advised, should consist of soup kitchens and canteens to provided nourishment for the children that would add to the already existing kitchens in conjunction with the fifty million pounds of remaining Red Cross Prisoners of War packages. Yet Hoover insisted that the respective Northwestern European nations receiving relief should bear the responsibility of funding with LendLease and Army monies assisting only when necessary. Meanwhile, long-term plans beyond the Army emergency assistance could be developed through planning by competent, qualified men who knew the needs of relief situations. ${ }^{11}$

By June 1945, the President had already received many, often "tragically urgent," messages from the leadership of famine affected nations, in addition to reports from "our people" in Europe, as Truman recounted in his memoir, on the imminent food emergency. Great Britain and Belgium, he noted, had always depended on imports for their populations, and as a result of the destruction of the war their agricultural production and shipping resources were either ruined or made neutral. On top of this was

\footnotetext{
${ }^{10}$ Ibid, 106.

${ }^{11}$ Ibid, 106.
} 
the reduced income from lack of exports and depletion of financial resources that had gone to previous military support. ${ }^{12}$

Truman knew the problems involved in dealing with a famine relief emergency were complicated, adding to his motivation to seek Hoover's experienced perspective. He used the example of Belgium and France reaching out to Argentina for meat supplies, forcing prices to dramatically raise. This resulted in the suggestion from the British, that the United States distribute their European military surplus food supply to the French and Belgians, under the presumption that these food stockpiles were still on hand. Yet as Truman indicated that same food supply had been allocated to the large number of German prisoners then under U.S. care. ${ }^{13}$

The American domestic meat supply, in Truman's perspective, possessed its own challenges. U.S. meat supply in the spring of 1945, Truman specified, had actually fallen below British per capita consumption. ${ }^{14}$ He asked Hoover, during the May $28^{\text {th }}$ meeting to provide guidance in domestic food administration. Elaborating in his summary of the situation, Hoover became critical of the War Food organization that had been formed during the first two years of the Second World War. He pointed out that any previous "experience of every nation" gained during the First World War had been utterly disregarded or rejected, asserting that the agency's economic standards impeded any success. The existence of black market prices and subsidies, as well as critical "local

\footnotetext{
${ }^{12}$ Harry S. Truman, Year of Decisions, 465

${ }^{13}$ Ibid, 465-466.

${ }^{14}$ Ibid, 466.
} 
famines," both of which had not been an issue during the previous war, Hoover asserted, were also among the major challenges. ${ }^{15}$

While providing the President with statistical information relating to domestic food product estimations, Hoover relayed his satisfaction with Truman's appointment of Secretary of Agriculture Anderson as Food Administrator. Speaking from his perspective as one time Food Administrator, he recommended that Truman grant Anderson total jurisdiction over buying, distribution, and production, reiterating the importance of prices and its foundation in distribution and production. ${ }^{16}$

Accordingly, Truman asked Hoover to assist Anderson on the reorganization of the national food agencies. The ex-president suggested combining conflicting agencies and authorizing price increases in wheat in relation to corn, as well as regulation of fat prices to avoid waste. This prompted Anderson to ask Hoover to help him motivate public interest in domestic food issues. Responding to an inquiry from Congressman Thomas Jenkins of the House Agricultural Committee, Hoover explained that facing the domestic and global food situation was not a "partisan question." The United States, he insisted, was not capable at that time to effectively face the predicament without complete collaboration from all those involved. He implied that any prospect of alleviating global famine depended on confronting and reorganizing the domestic food issues and challenges. ${ }^{17}$

\footnotetext{
${ }^{15}$ Hoover, "President Truman Requests My Assistance," 107.

${ }^{16}$ Herbert Hoover, Notes on Meeting With Truman, May 28, 1945, in A Documentary History, 41.

${ }^{17}$ Hoover, "The President Requests My Assistance," 108-109.
} 
Beyond global famine relief, Truman consulted Hoover on his perspective of foreign policy issues. Drawing from past experiences while working and living in Russia, China, and other areas of East Asia earlier and in later political office, one of Hoover's first responses was that the populations there were "Asiatics" and did not possess the same respect towards international agreements that Western nations did. Yet he added that it was critical for the United States to "take them as they were," and never go to war with any in that group or try to deceive them. Any war with Russia, Hoover declared, "meant the extinction of Western civilization," reiterating that he had no patience with those who advocated aggressive policies towards other nations. It was vital, Hoover believed, that the West should represent what it believed was just and right and stand firm within this stance. ${ }^{18}$

As Truman faced diplomatic challenges of an enlarging Communist Soviet postwar sphere, and the need to form his own foreign policy, Hoover demonstrated an adherence to Western non-interventionism. At the same time he advocated a declaration with both the British and possibly the Chinese regarding U.S objectives in the East Asia. When Truman inquired as to the nature of the "declaration," Hoover said the focus should be the complete restoration of Manchuria by Japan, along with an unconditional surrender of Japan that included total disarmament for thirty to forty years. He qualified this stance by saying that it had to be made clear "that the United States had no desire to exterminate the Japanese people," or bring about the elimination of their type of government, but instead hoped to support Japan in its return to prosperity and future

\footnotetext{
${ }^{18}$ Hoover, Notes of Meeting With Truman, 41.
} 
relations with other nations. ${ }^{19}$ Once Truman explained to Hoover that negotiations with Stalin were ongoing, moreover, he again asked for the ex-President's advice regarding future relations. The situation needed to be addressed practically, Hoover maintained, because the United States, not at war with them, should recognize Russia "as they were" yet be the representatives of freedom. ${ }^{20}$

Despite the lively exchanges and his ability to overcome past political slanders, Hoover walked away from the fifty-five minute meeting somewhat disappointed. He sensed that this initial consultation with Truman had been undertaken for political aims, seeing the President as firmly partisan, with no real objective of adding a Republican to his administration. ${ }^{21}$ It was the first time in many years that Hoover had been asked to participate directly in the Executive Branch of the U.S. government, and despite accounts of his emotion and appreciation of the event, he remained critical of its performance in approaching famine relief. Much of his discouragement also emanated from a feeling that the advice he offered only served to create a sense of national unity, and "that nothing more would come of it," Hoover lamented, "so far as I or my views were concerned."22

For his part, Truman reflected upon the meeting in his diary three days later as "pleasant and constructive," while pointing out that several of his staff who agreed to proceed with the meeting were "having trouble with their dignity and prerogatives." He indicates the close association already established between the Hoover and himself,

\footnotetext{
19 Ibid, 41.

${ }^{20}$ Ibid, 42.

${ }^{21}$ Edgar Rickard, Diary entry, May 30, 1945 in A Documentary History, 43.

${ }^{22}$ Hoover, Notes of Meeting With Truman, 43.
} 
declaring that "We discussed our prima donnas and wondered what makes 'em." Hoover had not indicated the casual points of the morning between the two, yet Truman expressed the observation of the difficulty "when a man get in close association with the President. Something happens to him..."${ }^{, 23}$ On the same day the President sent a short note to the ex-president acknowledging his satisfaction with the Memorandum of the meeting that Hoover had sent him and expressing optimism about the usefulness of the experienced advice. ${ }^{24}$

Indeed Truman was genuine in expressing his appreciation of Hoover's advice about the famine situation as well as the end of the war with Japan, and took the suggestions seriously. The President had passed on what Hoover had said in his Memorandum to Anderson and Fred M. Vinson of the Office of War Mobilization and Reconversion for analysis. Next he sent the document to acting Secretary of State Joseph L. Grew, who had recently replaced the retiring Cordell Hull, for additional critique. Grew essentially realized the potential in Hoover's recommendations regarding U.S. objectives in relations with Japan, sending a response within a memorandum of his own on June 13. Grew commented that Hoover's ideas about an unconditional surrender by the Japanese, demilitarization of that nation, future protection of islands once under threat by the Japanese, and other suggestions fell well within the policies of the "post-defeat treatment of Japan" being considered by the State Department. He also pointed out that

\footnotetext{
${ }^{23}$ Harry S. Truman, Diary entry, June 1, 1945, Joint website by Herbert Hoover Presidential Library and Museum and Harry S. Truman Presidential Museum and Library, www.trumanlibrary.org, 5-6.

${ }^{24}$ Truman, Note from Truman to Hoover, June 1, 1945, A Documentary History, 53.
} 
U.S. policy included an even broader scope for the terms of surrender by Japan, than what Hoover had endorsed. ${ }^{25}$

At the same time, Hoover's recommendations towards food relief in Europe would not be addressed until later in 1946. The urgent hunger program in Europe, despite Truman's immediate direction to the War Department for emergency relief in liberated nations, remained disorganized and largely ineffective. In the Allied occupied section of Berlin, for example, military procedures and political policies dominated the region and were greatly hindered by only having one central railway line available. Any daily transportation of supplies from the west became affected, while the existence of a one hundred mile stretch of an automobile superhighway in the Soviet sphere was yielded to the Russians for their potential needs, as the Allies did not have any substantial rights to its use. $^{26}$

Hoover and Truman did not communicate during the months after that late May meeting at the White House, and would not do so until August 22, beginning another series of shared counsels on other matters that revolved around domestic events and policies. After Truman returned from the Potsdam Conference earlier that month, Hoover wrote to the President urging him to exempt men under the age of twenty-one from the military service draft who desired to pursue their education, and advocated for increased salaries of returning college faculty to meet the rising costs of living. A large part of

\footnotetext{
${ }^{25}$ Joseph M. Grew, Memorandum for the President, Department of State, Washington D.C., June 13, 1945, A Documentary History, 54-55.

${ }^{26}$ Frank E. Mason, Letter to the North American Newspaper Alliance, New York City, New York, August 13, 1945, Herbert Hoover Presidential Library and Museum, West Branch, Iowa, Frank E. Mason Papers, Box 5, Articles by Frank E. Mason, 2-3.
} 
Hoover's message was based on the premise that colleges could suffer from lack of enrollment, and that potential students should not need to struggle in the decision to engage in higher education. ${ }^{27}$

While Truman replied to Hoover's suggestion with appreciation, he pointed out that various efforts to accommodate service men in the process of being demobilized were underway, but would often take somewhere between six months to a year to fulfill. Essentially he did not address the point that Hoover had attempted to put forth regarding exemptions from the draft, but rather implied that he would do anything possible to "meet the present emergency and continue to a prosperous future." Truman did indicate though that he would attempt to clarify the topic that Hoover wished to consider in Congress in hopes of a rapid resolution to the issue. ${ }^{28}$

Signs of Quaker anti-military roots seemed to extend through Hoover's considerations towards assisting those interested in education. He wrote back to Truman in continued support of the draft exemptions based on the need for national readiness through a supply of professionals such as doctors, engineers, and scientist that could be attained with the edifying of the next generation of men obligated by the military. Hoover asserted that "we have already lost four or five annual crops of such men," through the events of the world war. Prolonged maintenance of the draft, he concluded, only increased the lack of skilled professionals in the nation. Seemingly impatient with

\footnotetext{
${ }^{27}$ Herbert Hoover, Telegram from Hoover to Truman, August 22, 1945, Washington D.C., A Documentary History, 55.

${ }^{28}$ Harry S. Truman, Telegram from Truman to Hoover, August 24, 1945, Washington D.C., A Documentary History, 56.
} 
Hoover's persistence, or under pressure of his office, Truman tersely responded that he was "well aware of the situation," and had been striving to "alleviate the situation" one that would be taken care of to an acceptable end. ${ }^{29}$ Although the two had known one another for over three months and the acquaintance had been cordial, an obvious friendship still had to become evident.

The draft exemption issue may have challenged the relationship, but was later potentially strengthened by communication from Hoover regarding reorganization of the Executive Branch of the federal government. Truman had already extended efforts to address the concern, but through mutual friend Colonel John Callan O'Laughlin he received a letter written by Hoover to Congressman George Bender describing his view of the President's endeavor. Hoover pointed out that "six successive Presidents over 35 years have recommended such reorganization," noting that the waste and controversy of the policies amongst the executive bureaus had been a disgrace for that same length of time. The President wrote gratefully to Hoover, indicating that the measure he had proposed, H.R. 4129, provided the President the power to reorganize the executive branch, as a part of a struggle long overdue. ${ }^{30}$ Subsequently, Hoover indicated to O'Laughlin that Truman, when confronting his own Democratic party, did not possess the same public affects in combating opposition in the Legislature and not the same "coercion and bribing with political spoils" that he felt F.D.R. had exploited within his

\footnotetext{
${ }^{29}$ Harry S. Truman, Letter to Hoover, September 6, 1945, A Documentary History, 57-58.

${ }^{30}$ Truman, Letter to Hoover, October 11, 1945, A Documentary History, 58-59.
} 
tenure. Nevertheless, he felt that Congress would indeed move ahead with distinct determination in necessary efforts. ${ }^{31}$

By the end of 1945, the bond between Hoover and Truman had not evolved into one very far beyond famine issues and a few political discussions. Yet testimonies from figures connected with Hoover such as Senator George D. Aiken of Vermont, who later became involved in the implementation of the Hoover Commissions, relate the huge benefits that the ex-president gained by Truman repeatedly consulting him for advice. "One thing that helped him[Hoover] more than anything else was the consideration paid to him by the President Truman," Aiken recalled in a 1971 interview. "I think he helped President Truman as much as President Truman helped him." 32 Former New Jersey Governor Charles Edison, son of inventor Thomas Edison, acquainted with Hoover before he became President and after, essentially concurred with this in a 1966 interview. Edison stated that Hoover had related to him that "Harry Truman was not nearly as bad as people made out he was, and that at least he had the courtesy to come and see him and talk things over with him." Admitting that he was not a big enthusiast of Truman's actions in the Korean War, Edison still asserted "There are a many people who think that Harry Truman deserves a great deal of credit for the manner in which he called Mr. Hoover to aid him." 33

\footnotetext{
${ }^{31}$ Herbert Hoover, Letter to Colonel John Callan O'Laughlin, December 27, 1945, A Documentary History, 59.

${ }^{32}$ Senator George D. Aiken, Interview by Stephen V. Feeley for the Herbert Hoover Presidential Library, West Branch Iowa, July 1971, Oral Histories, Herbert Hoover Presidential Library and Museum Archives, West Branch Iowa, 5.

${ }^{33}$ Charles Edison, Interview by Raymond Henle, Director, Herbert Hoover Presidential Library, West Branch, Iowa, December 6, 1966, Oral Histories, Herbert Hoover Presidential Library and Museum Archives, West Branch, Iowa, 6-7.
} 
Whatever these personal considerations, the famine problems in Europe had not gone away as 1946 dawned, and the President along with members of his administration continued to seek solutions, or at least gain an effective level of knowledge and command on how to approach it. Yet Hoover felt that not a lot of progress had been achieved during the remainder of 1945 and into the next year, based on both his and Secretary Anderson's proposals. Although he reiterates that a suitable organization had not been set up to meet the famine needs of post-war Europe, however, he pointed to inadequate harvests in the Northern Hemisphere that same fall and the added weights of the war with Japan, the Potsdam Conference, and the increasingly apprehensive relations with the Soviet Union to suggest that the President and Congress were not at fault. ${ }^{34}$

In the midst of these obligations Truman, along with Secretary Anderson, reached out to Hoover to seek advice a second time about what could then be done to alleviate the world food emergency. Anderson telephoned Hoover early in February 1946, who advised him to urge the President to voice the national need for food conservation and the creation of a relief program. Truman proceeded to do this on February 6 in a press statement describing the food crisis that faced the world as one that had never been experienced before in modern times, and at such a high level. He proclaimed that more people were encountering starvation and potentially death at that point than "in any other year and perhaps more than in all the war years combined." Truman reiterated the need for cooperation among the American people and its industries, while indicating that he

\footnotetext{
${ }^{34}$ Herbert Hoover, "We Begin World Organization to Meet the Famine," An American Epic: The Guns Cease Killing and the Saving of Life From Famine Begins, 1939-1963, Volume IV (Chicago: Henry Regnery Company, 1964), 113.
} 
had directed the appropriate channels of the Government to initiate necessary measures regarding regulation of food related products and producers, particular with grain and bread, and directing the control to be administered by the Department of Agriculture. ${ }^{35}$ Hoover advised Anderson that he needed to obtain authority from the President to be sanctioned as the Food Administrator. ${ }^{36}$

Anderson placed a second call to Hoover on February 25 while the former President was on a fishing trip in Florida. Anderson relayed to Hoover's secretary that he was speaking for the President in regards to having the ex-President return to Washington and advise on "the crisis, which was steadily worsening." ${ }^{37}$ Anderson indicated that he and others in government were eager to begin the Civilian Food Conservation program as soon as possible, separate from the Department of Agriculture. Many names had emerged as to who could assume the chairmanship, such as St. Louis banker Chester Davis who later officially filled the position. At the same time, the Secretary expressed his appreciation for Hoover's help during the previous summer, and offered him the position of Honorary Chairman for the organization. Anderson assured Hoover that this "was not a politically cooked up arrangement," but that the administration was "solely interested in conservation." 38

\footnotetext{
${ }^{35}$ Harry S. Truman, Statement by President Truman Announcing Emergency Measures to Relieve the World Food Shortage, February 6, 1946, Public Papers of Harry S. Truman: 1945-1953, Harry S. Truman Library and Museum, 1-2.

${ }^{36}$ Walch and Miller, A Documentary History, 62.

${ }^{37}$ Hoover, "We Begin World Organization," 114.

${ }^{38}$ Clinton Anderson, Transcript Copy of Telephone Conversation, February 25, 1946, Harry S. Truman Library, 1.
} 
In a detailed reply to Anderson the next day, Hoover accepted the position of Honorary Chairman for what evolved into the Famine Emergency Committee. Again he offered a step by step outline, within the lengthy telegram, of the necessary phases of voluntary organization along with measures of government action that included delegating strong authority to State Department of Agriculture administrators and those at the county levels. ${ }^{39}$ Truman sent a telegram on February 27 inviting a dozen citizens of distinction to the White House for a March 1 meeting to begin discussions of the program and methods of encouragement for private citizens in conservation of food. Hoover had yet to realize that this same meeting would signal the start of the most active three months of his life since the day he left the presidency in $1933 .{ }^{40}$

The ex-President arrived for a second meeting with Truman on March 1, just before noon and spent the next thirty minutes in private conversation with the President about the pending world famine. ${ }^{41}$ Hoover told Truman that the figures that Anderson had already ascertained were not accurate and that there was a large span between those statistics and the reality of the famine catastrophe. He explained that the government's statistics could only minimally meet the needs of the hungry to avoid starvation, while his own assessment at that point indicated the necessary cooperation between the United States and "all nations of the world to fight the famine."42 Essentially Hoover indicated that the statistical information that the government was relying on needed to be

\footnotetext{
${ }^{39}$ Hebert Hoover, Telegram from Herbert Hoover to Clinton Anderson, February 26, 1946, A Documentary History, 63-65.

${ }^{40}$ Walch and Miller, A Documentary History, 65.

${ }^{41}$ Ibid, 66.

${ }^{42}$ Hoover, "We Begin World Organization," 116.
} 
reexamined before moving forward. He pointed out that the United Nations Relief and Rehabilitation Administration (UNNRA) as well as the Combined Food Board, the temporary wartime economic resource allocation organization of the United States and Great Britain, were the only real avenues of relief. Still the supply that UNRRA provided only met twenty percent of the global famine needs, as the largest portion of relief in Europe already been delivered to the Ukraine and communist dominated states of Poland, Czechoslovakia, and Yugoslavia. Hoover told Truman that he saw no real prospect in UNNRA's ability to unite the world into action for relief, and agreed with Anderson that the only conceivable organization available was the Combined Food Board. ${ }^{43}$

Later that afternoon Truman, along with Hoover, Anderson, and Secretary of Commerce Henry A. Wallace, made statements to the press and to the participants of the Food Conference in the East Wing Conference Room of the White House. The remarks that signaled the official establishment of the Famine Emergency Committee began with the President reiterating the "very serious condition" regarding world food consumption. He asked for any advisement and assistance of the assembled group in the room "It is the most important meeting I think we have held in the White House since I have been President," Truman declared. ${ }^{44}$

Hoover reiterated the need and obligation of the American people to meet the needs of the starvation caused by the war. "The last great reservoir from which starvation

\footnotetext{
43 Ibid, 117.

${ }^{44}$ Harry S. Truman, Press Conference Statements by Truman, Hoover, Anderson, and Henry A. Wallace, March 1, 1946, Washington D.C., A Documentary History, 66-67.
} 
can be halted is in these United States," he warned. ${ }^{45}$ The idealism that Hoover felt towards America and the potential of its people surfaced in these statements. Yet he still expressed a degree of pessimism about the success of the food program and privately conveyed his doubts about Truman's abilities. Hoover expressed his view that Davis and Anderson both realized the gravity and needs of the famine situation, but pictured the President as being rather dense and incapable of understanding the critical dimensions of any issue. Hoover privately confessed that he could not comprehend how the United States “ever was governed by such a mediocre man," and maintained misgivings about whether the post-war President would ever be able to achieve a valuable foreign or domestic policy. ${ }^{46}$

Personality conflicts were apparent between the two, even if they did not realize it. Ferrell describes an interview with Truman several years after his presidency regarding his entrance into politics. Truman indicates that one of the most valuable lessons he gained from his earliest political years was the essential need to start in politics on the local level. He pointed out how Hoover, for whom he expressed his strong admiration, did not acquire the same formative political experience. Hoover basically had started out at the top, only having the experience of an engineer, Truman pointed out, lacking in the necessary background and knowledge of politics. ${ }^{47}$

\footnotetext{
${ }^{45}$ Herbert Hoover, Press Conference Statements by Truman, Hoover, Anderson, and Henry A. Wallace, March 1, 1946, A Documentary History, 67

${ }^{46}$ Rickard, Diary Entry, March 2, 1946, Truman Museum and Library, 1; Diary Entry, March 13, 1946, A Documentary History, 69.

${ }^{47}$ Harry S. Truman Interview, October 21, 1959, Cited in Robert S. Ferrell, Harry S. Truman (Columbia: University of Missouri Press, 1994), 99.
} 
Similarly, historian Bruno Cabanes asserts how the personality of Hoover indeed did not coincide well with the world of politics. Critics had noticed early on, even before entering the political sphere, that he lacked the charismatic qualities and seemed shy, rather sensitive, and continually looking downward. Publicly expressing himself, as other politicians like F.D.R. excelled at, was difficult for Hoover, not coinciding well with expected or typical political characteristics or mannerisms. He never improved into a good public speaker, and his demeanor most often accompanied an absence in sociability and antipathy for personal, spoken communication as opposed to written memorandum. At the same time, Hoover's humanitarian focus remained on providing relief to others that he hoped to help through his own past experience and knowledge, thereby remaining faithful to the qualities of his Quaker upbringing in both his endeavors and demeanor. As he had led the one of the largest humanitarian efforts through the Committee for Relief in Belgium (CRB) during the First World War, and the American Relief Administration (ARA) shortly after, he now symbolized the next effort to relieve the most sizable famine in world history. ${ }^{48}$

Filling the role as Honorary Chairman, Hoover stressed to Truman the absolute necessity of creating a solid mission, instigated by the President, to all of the major nations of the world to participate in fighting world hunger. Both Hoover and Anderson agreed and insisted that a long, drawn out international conference in Washington D.C. that the State Department had proposed to initiate, with all of the accompanying details,

\footnotetext{
${ }^{48}$ Bruno Cabanes, The Great War and the Origins of Humanitarianism, 1918-1924 (New York: Cambridge University Press, 2014), 208.
} 
would not be quick enough to address the problem of global famine. The need was immediate, Hoover declared to the Truman, to "win a race with the famine," coordinate with the heads of state in the famine afflicted nations, and gather necessary facts on hunger relief requirements and at least agree with the leaders on minimal food supply needs. These actions would assist in the conservation efforts as well, aided by press coverage, and reinforce the seriousness of the famine situation. Hoover asserted that the overall effort against the famine could also assist in diplomacy between the U.S. and its former Allies to cooperate in the mutual endeavor to help "feed a recent enemy," alluding to Germany and its population. ${ }^{49}$

Truman asked Hoover to undertake this mission and travel to Western Europe, largely as the President indicated because of the ex-president's influence in those nations through his past relief management of the CRB there after the First World War. Hoover accepted, yet was admittedly hesitant due to his age and, as he later wrote, because of other administrative obligations of various "educational, scientific, and charitable institutions at home." He requested that Truman inform the U.S. representatives in the European nations that were to be visited, put themselves at the mission's and Combined Food Board's disposal and consent to the necessary recommendations that would emerge. $^{50}$

\footnotetext{
${ }^{49}$ Herbert Hoover, "We Undertake To Co-ordinate The World In Battle Against Famine," An American Epic: The Guns Cease Killing and the Saving of Life from Famine Begins, 1939-1963, Volume IV (Chicago: Henry Regenery Company, 1964), 122.

${ }^{50}$ Ibid, 123.
} 
The President granted Hoover the liberty to choose the members of the mission that would assist him, and indicated his intention of providing the best possible air transport to fulfill the operation. Consequently, Hoover obtained the "voluntary membership" of former U.S. diplomat and Ambassador Hugh Gibson, Captain Hallam Tuck of the U.S. Navy, American humanitarian and businessman Maurice Pate, and aide Perrin C. Galpin, all of whom had assisted the famine relief work during the First World War. In addition he recruited the help of Frank A. Mason, an experienced foreign correspondent in Europe and former President of the International News Service, to assist in coordination with the press in foreign nations. Dr. Julius Klein, former Department of Commerce commercial attaché in Latin American countries, and later U.S.

Undersecretary of Commerce assisted the mission when it traveled to South America to secure food resources. Hugo Meier, “an accomplished secretary” as Hoover describes, was added to the team for recording purposes. Additionally Hoover asked Dr. D.A. Fitzgerald to accompany the mission, not only for his medical capacities, but for competent recommendations regarding food allotments within the affected nations, so as to provide assurance to Anderson and the Combined Food Board of fair and equal distribution. ${ }^{51}$ Two others, John Brown Mason and Charles Delzell, both former members of the Stanford University faculty, were also listed on the roster of team members. ${ }^{52}$

\footnotetext{
${ }^{51}$ Hoover, "We Undertake To Co-ordinate," 123.

${ }^{52}$ Famine Emergency Committee, General Personnel File, Herbert Hoover Presidential Library and Museum, Box 148.
} 
Military aide Captain Ivey T. Westmoreland and Flight Surgeon Delbert F. Rey, M.C. completed the main mission group. ${ }^{53}$

The President bestowed the group with a C-54 plane with two pilots and six crew members. ${ }^{54}$ Hoover dubbed plane "The Faithful Cow" because of the way the wing flaps emitted a mooing sound when they were lowered. ${ }^{55}$ A second plane was designated to follow behind for emergency and repair support. ${ }^{56}$

On May 16, 1946 at 7:15 p.m., one day before the FEC party's scheduled departure from the United States, Hoover delivered a public radio address from New York City to inform listeners of the mission's purpose and intents. Describing the request from the President and Anderson for advice on the famine emergency, he spoke of the beginning of a reprieve of the crisis through what the ex-president referred to as the Emergency Food Administration. The emergency "is an issue of religious faith and morals which affects our country as a whole and each individual," Hoover emphasized. He stressed to the audience the need to save human lives as "a moral and spiritual duty," suggesting the scenario of inviting hungry neighbors and their children in need to share in the food supply that the listener had to offer. It was the same in foreign nations, the former President indicated, and as neighbors the "helpless women or children" were hungry and in dire need. Through the help of voluntarily conserving food one could save

\footnotetext{
${ }^{53}$ Maurice Pate, Diary, p. 6, Famine Emergency Committee General File - Diaries, Hoover Library, Box 148.

${ }^{54}$ Ibid, 6.

${ }^{55}$ Eugene Lyons, Our Unknown Ex-President: A Portrait of Herbert Hoover (Garden City: Doubleday \& Company, Inc., 1948), 53.

${ }^{56}$ Hoover, "We Undertake To Co-ordinate," 124.
} 
lives of those same people. Helping the afflicted, Hoover reiterated, provided the means for "health, courage and faith" for a desperate and dispirited famine stricken population, underscoring a plea for compassion and understanding by Americans. ${ }^{57}$

Hoover and the FEC mission team took off the next morning, Sunday May 17, from LaGuardia Airport en route to Paris after a stopover in the Santa Maria Azores. ${ }^{58}$ It had been nearly nine months since Hoover had met Truman and began any discussion about what to do about the famine in war-torn Europe. Now over three quarters of a year after the beginning of the association, the President had the ex-President and known humanitarian manager heading to the ravaged continent of Europe and elsewhere to assess what America could do for its desperate and hungry people. Now in "The Faithful Cow" C-54 airplane with an assembled team aiming for the shared objective to avert famine in Europe, Hoover hoped to build upon his reputation in the next several weeks and overcome his reservations about President Truman to build a viable working relationship.

\footnotetext{
${ }^{57}$ Herbert Hoover, Radio Address, "Herbert Hoover on World Famine," March 16, 1946, 7:15 p.m., ABC, New York, New York, A Documentary History, 71.

${ }^{58}$ Hugo Meier, Diary Entry, March 17, 1946, p.1, Famine Emergency Committee General-Diaries File, Herbert Hoover Library and Museum, Box 148.
} 


\section{Chapter 3}

Into the Mission

In Our Unknown Ex-President: A Portrait of Herbert Hoover (1948), historian Eugene Lyons describes Hoover's trip to Poland in 1919 as head of European food relief following the end of the First World War. Earlier reports of conditions in Warsaw told of the absence of children playing in the streets, indicating their weakness, malnourishment, and lack of spirit. ${ }^{1}$ Led by Hoover, the American Relief Administration (ARA) had fed over 1.5 million men, women, and children in ravaged Poland during six months in 1918. As U.S. Food Administrator he returned the next year. Although Polish authorities had less than twenty-hours of advance notice of the visit, an estimated fifty thousand boys and girls assembled and paraded in his honor for several hours into the evening along an old racetrack, many carrying homemade American flags or the tin cups given to them by the ARA used for lunch earlier that day. The modest presentation to Hoover of a stray rabbit caught at the edge of the track by a large group of the children, witnesses reported, brought the humanitarian official to tears. ${ }^{2}$

The reputation that American-led relief in foreign nations had acquired during the war and subsequent years earned the name "Hoover relief," beyond the official organizational titles of the Commission of Relief in Belgium (CRB) or the ARA. Lyons

\footnotetext{
${ }^{1}$ Eugene Lyons, Our Unknown Ex-President: A Portrait of Herbert Hoover (Garden City: Doubleday \& Company, Inc., 1948), 38.

${ }^{2}$ Ibid, 38-39.
} 
suggests that while nations embrace their respective heroes, like David Lloyd George of Great Britain or Georges Clemenceau of France, Hoover "was a hero to nearly all nations, victorious and defeated alike," despite his aversion to the typical and expected norms of politics. ${ }^{3}$

When Hoover and the Famine Emergency Committee (FEC) team landed in Paris on March 19, 1946 the scene was not as large or sensational as the celebration twentyseven years earlier. The welcoming committee was comprised of the American Ambassador to France Jefferson Caffery and several representatives of the French President Félix Gouin and Minister of Foreign Affairs Georges Bidault. ${ }^{4}$ A number of reporters and photographers were also present to record the arrival of the FEC mission. ${ }^{5}$ Hoover, remembering the mission largely through his memoirs in An American Epic, Volume IV (1964), recalled the group had "arrived with anxious minds." "This was to be our first test," he remembered, "of whether we could get the co-operation for the necessary self-denial among thirty eight different nations to save hundreds of millions of lives."

In spite of the much smaller reception than years before, the ex-President remembered that once he and the group met with Gouin and Bidault, the French President easily recalled Hoover's service during the First World War. Gouin consequently

\footnotetext{
${ }^{3}$ Ibid, 24.

${ }^{4}$ Herbert Hoover, "France, Italy, and the Vatican," An American Epic: The Guns Cease Killing and the Saving of Life from Famine Begins, 1939-1963 (Chicago: Henry Regnery Company, 1964), 131.

${ }^{5}$ Hugo Meier, Diary Entry, March 19, 1946, Hugo Meier Diary, Herbert Hoover Library and Museum Archives, Famine Emergency Committee, General Diaries File, Box 148, 1.

${ }^{6}$ Hoover, "France, Italy, and the Vatican," 131.
} 
expressed that it was a profound "blessing for the world" that Hoover had assumed such a job once again. The French leaders were significantly distressed at both their own food situation and reports from other areas of the globe. They described what they already knew of their acute situation to the FEC group, pledging complete cooperation in whatever was necessary to deal with the situation. ${ }^{7}$

Meanwhile, Hoover and the FEC taskforce immediately went into discussion with both the French and American officials already present in France to analyze the known data which had been assessed up to that point. Subsequently, arrangements were made for members of the FEC staff of technical advisors to meet with the French Agricultural and Food Ministers. Hoover knew that seven members of the French Ministry were communists who had emerged from the French wartime underground force, while the French Minister of Agriculture, Francoís Tanguy-Prigent, was a Socialist completely unknowledgeable about agriculture. Yet Hoover had more confidence in the Minister of Food, Henri Longchambon, who he sensed was a "honest, skilled, and experienced man."8

Hoover and his staff, upon reviewing their statistics on food relief needs, realized that the information agreed with current French assessments. At the same time, members of the FEC group not involved in this initial analysis were sent into the public field to gather additional data, along with information from the Red Cross and the U.S. Army regarding previous relief efforts. Maurice Pate, of the FEC, gathered statistics concerning

\footnotetext{
${ }^{7}$ Ibid, 131.

${ }^{8}$ Hoover, "France, Italy, and the Vatican," 132.
} 
the status of children and the elderly and the proliferation of famine related diseases. In doing so, Pate utilized both government statistics and visits to the homes in slum areas to gather information for the FEC first hand from the victims of the food shortage. At the same time, Hallam Tuck and Perrin Galpin, both members of the FEC taskforce, visited the French rationing agencies and institutions already established to help feed the public. ${ }^{9}$

French food rations had already been decreased prior to the FEC's arrival, and further reduction was anticipated in bread and fat rations, resulting in an estimated individual daily consumption of 1,200 calories. With the available food stocks in France during the assessment, it became clear that until the next harvest, food rations could only provide 700 daily calories to each individual. Hoover asserted that, "Neither a government nor a people could survive on such a regimen." ${ }^{\prime 10}$ Along with Dr. Dennis A. Fitzgerald of the FEC group, Hoover comprised a tentative outline of the estimated minimum supplies that should be imported to France, from April 1946 and through the following critical harvest months, to achieve the lowest average individual 1,500 calories daily requirement. ${ }^{11}$

Fitzgerald and Agriculture attache of the Paris Embassy, a Mr. Thibodeuax, left France on March 21, separate from the main FEC group, to fly to French North Africa to conduct necessary investigations. ${ }^{12}$ Assessing this need, Hoover knew that the North African French colonies normally had been a source of supply for France, but needed

\footnotetext{
${ }^{9}$ Ibid, 132.

${ }^{10}$ Ibid, 132.

${ }^{11}$ Ibid, 132.

${ }^{12}$ Frank Mason, Dear Julius Letters, March 22, 1946, p. 2, Famine Emergency Committee-General File, Herbert Hoover Library and Museum, Box 147.
} 
major assistance as a result of droughts and locusts. Yet he pointed out that the summer harvest would precede that of France and the French North African possessions could become important sources of food for the French population at home. ${ }^{13}$

Frank Mason, another member of the FEC group, referring to Hoover as "The Chief," the name that he and the rest of the FEC team used for the ex-President on this mission and had used decades earlier during the CRB years, noted that his boss was generally pleased with the assistance and attitude of the French. Yet Mason asserts that the French were in a state of confusion, in large contrast to the more organized government that Hoover experienced at the end of the First World War. ${ }^{14}$

Similarly, FEC member Hugh Gibson noted in his diary of the "unbelievably depressing" atmosphere in Paris. The mood of the people that he encountered seemed "listless" and easily bent to complaining without any sense of optimism. He points out the large difference between what he saw in the French people and reports describing the Belgians as "busy as bees" and interested in trying to help themselves. Gibson relates the French excuse that "they had been through too much and cannot be expected to react."15

Hoover noted in his assessment of the French situation that Longchambon, though having no experience in both government and economics, insisted that he and his subordinates were doing the best they could in the situation, essentially conceding that maintenance of public order and avoidance of starvation directly depended upon a

\footnotetext{
${ }^{13}$ Hoover, "France, Italy, and the Vatican,"133.

${ }^{14}$ Mason, Dear Julius Letters, March 22, 1946, 2

${ }^{15}$ Hugh Gibson, Diary Entry, March 20, 1946, Paris, The Food Mission Diaries of Hugh Gibson (1946 and 1947) p. 11, Hoover Institution Archives, www.digitalcollections.hoover.org.,
} 
solution to the famine situation. ${ }^{16} \mathrm{He}$ also indicated that the postwar French government were "products of the Resistance Movement." At the same time, he felt the French were exceptionally disorganized regarding their food supply, and sensed the general population as leaderless, lethargic and disheartened, one expecting the United States to "feed them and restore their economy." The ex-president concluded that to save western civilization famine relief in Western Europe had to be undertaken first. ${ }^{17}$

As France was a strong test and starting point for the FEC team, Italy did not prove as disordered upon their arrival in Rome on March 22. The United Nations Relief and Rehabilitation Administration (UNNRA) had already been positioned to head food imports into that nation, led by Spurgeon M. Keeny, an acquaintance of Hoover's and fellow relief organizer during the First World War. Hoover accordingly held strong faith in Keeny's abilities, experience, and ability to secure accurate information. Hoover and the FEC team relayed the estimated daily requirement of 1,500 calories in coordination with the known, available supplies, advising the Combined Food Board of the needs for the coming months of May, June, and July. On May 25 Hoover addressed the Italian population through the American press, informing them of the decreased food production, the nutritional and supply statistics, and the Italian leadership's optimism that other nations like Brazil and Argentina would realize their plight and help bolster food

\footnotetext{
${ }^{16}$ Herbert Hoover, "My Impressions of France," Summary of FEC Assessment in France, March 26, 1946, p. 2, Famine Emergency File - General Diaries: Herbert Hoover Diaries, Herbert Hoover Presidential Library and Museum, Box 148.

${ }^{17}$ Ibid, $2-4$.
} 
supplies. His statement stressed that starvation would not occur unless supplies ceased to be imported. ${ }^{18}$

While in Italy, Hoover deemed that a "An important part of our problem all over the world was to convince every individual of the need for self-sacrifice in order to save food." The mission made it a key objective to procure the cooperation of the Vatican to encourage help among Catholics and crucial assistance from Latin America. Meeting with Pope Pius XII for one hour on March 23, Hoover and Gibson gained assurance from His Holiness of the Vatican's commitment to aid in "every way possible." The next day the Vatican contacted the FEC to acquire technical knowledge of the food supply needs. ${ }^{19}$ A brief meeting with authorities in Switzerland on March 25, arranged by U.S. ambassador Leland Harrison, comprised the next leg of the FEC mission and resulted in assurances that a small food surplus in that nation could be sent to assist France and Italy. $^{20}$

Hoover returned to Paris on March 26 to deliver a public radio address, strongly desired by the French leadership. He relayed the scope of the famine, supporting his statements with statistics, and indicating how the FEC would assess and assist before the next harvest. Pointing out the need to not be misled by false reports by Americans travelers of a better food situation than existed because of black market activity, Hoover

\footnotetext{
${ }^{18}$ Hoover, "France, Italy, and the Vatican," 136-137.

${ }^{19}$ Ibid, 137-139.

${ }^{20}$ Herbert Hoover, "Switzerland, Czechoslovakia, and Poland," American Epic, Volume IV, 141.
} 
hoped to encourage both the French and Italian people to stand firm in their commitments. $^{21}$

Assessing the need of Czechoslovakia while in Prague beginning March 27, the FEC members learned that UNNRA had already supplied some relief during the preceding nine months, under the leadership of Russian Communist Peter I, Alekseev, director of UNNRA for that nation. Gibson, Maurice Pate, and Hallam Tuck, while conferring with various acquaintances in Prague, took away a much deeper understanding of the "political forces in motion" in Czechoslovakia. Hoover's memoir of the food relief project noted that nine of the Czechoslovakian Cabinet members were now Communists, and that non-Communist former acquaintances felt helpless in the situation. Still, Hoover points out that without help from UNNRA, Czechoslovakia would have been in far worse condition although the team observed heavy suffering among the children and the need to increase rationing. ${ }^{22}$

The situation in Poland was no less disturbing when the FEC mission arrived in Warsaw on March 28, a far cry from the celebratory scene of 1919. Hoover observed that the entire Government was Communist with the exception of one member. Pate and Gibson, the latter the first U.S. Minister to the new Poland of 1919, heard testimonies from many of their old friends in Warsaw about the "terrors of the Communist regime." Gibson described the scene of the city destroyed by Nazi forces months before as a

${ }^{21}$ Herbert Hoover, "Remarks by Mr. Hoover Over ---- National Radio From Paris, France," March 27, 1946, pp. 1-3, Famine Emergency Committee File, General Diaries, Herbert Hoover Presidential Library and Museum, Box 148.

${ }^{22}$ Hoover, "Switzerland, Czechoslovakia, and Poland," 141-142. 
"horror," with virtually no house left standing or undamaged, with false fronts on several buildings serving as shops to sell or barter with next-to-nothing items. ${ }^{23}$

In a reply to questions from American press members in Warsaw, Hoover related that "This is the worst situation we have seen so far in every respect." Yet he recalled that the Polish people possessed a distinct "hope and gallantry" as they sought to pull themselves out of the "greatest physical, political, intellectual and moral destruction ever known." At the same time, Hoover assured the press that his mission to Poland was not political but "solely concerned with food." While an estimated more than five million Poles were killed in the war, Hoover pointed out, 1,100,00 orphans and half-orphans remained, with five million children in immediate need of appropriate relief, and nonexistent relief organizations. ${ }^{24}$ In addition to the population of Warsaw and other areas of Poland, Hoover recalled, millions of refugee Poles from eastern territories annexed by the Soviet Union, and evicted Germans from the same areas added to the burden. In response, Hoover and the team advised the Combined Food Board that UNNRA should receive a total of 340,000 tons of cereals, condensed milk, and fats for Poland between May and August. ${ }^{25}$ In a reply to a speech made by Polish President Boleslaw Bierut on the night before the FEC team departed Poland, Hoover acknowledged that "We know we cannot have peace in the presence of the spectre of famine..."; "There were few

\footnotetext{
${ }^{23}$ Ibid, 143; Gibson, Diary Entry, March 29, 1946, Hugh Gibson Diaries, 58.

${ }^{24}$ Hoover, "Switzerland, Czechoslovakia, and Poland," 144-145.

${ }^{25} \mathrm{Ibid}, 145$.
} 
satisfactions to be had from witnessing the reality of communism in Poland," he recalled. ${ }^{26}$

The Finnish Government "was menaced by Soviet Russia," Hoover noted after the FEC mission landed in Helsinki on March 30, as one quarter of that nation's government already was occupied by members of the Communist Party. The Finns, he explains, were receiving a small monthly import of wheat from Russia, in exchange for a vast amount of Finnish commodities. Yet Hoover was largely impressed by the major effort already underway to care for the children there, while the nation's food administration demonstrated great efficiency. Still the FEC's concerns were aimed at lower income, urban groups, people in areas decimated by the German military, and refugees from areas now under Soviet control. ${ }^{27}$ At one point during the stop while driving to a lunch with authorities, Hoover made a stop at a school where he was saluted by the students there who held American flags and a resonant song of thanks. ${ }^{28}$

Hoover pressed the Swedish government to assist the Finnish neighbors in their plight. Swedish officials, during the April 1 visit by the FEC, informed Hoover that their government had already obtained about 80,000 tons of grains in the United States as well as Argentina, though it had yet to be shipped. In response to the FEC mission, Hoover noted, the Swedish government canceled the shipments to make the grain available to the use of the Combined Food Board. Concluding from reports made by Maurice Pate, the

\footnotetext{
${ }^{26} \mathrm{Ibid}, 146-147$.

${ }^{27}$ Herbert Hoover, "Finland, Sweden, and Norway," An American Epic, Volume IV, 149-148.

${ }^{28}$ Gibson, Diary Entry, April 1, 1946, Hugh Gibson Diaries, 81.
} 
health of Swedish children appeared satisfactory before the FEC mission travelled to Oslo the next day. ${ }^{29}$

Norway had been pillaged by the Germans during the war with the loss of railway resources and farm animal stock. Upon arrival in Norway the FEC was provided a comprehensive analysis of food supply needs prepared by the American Embassy staff, while UNNRA, according to Hoover, had given the government no help in the endeavor. ${ }^{30}$ Though health in Norway had been assessed as "generally good," children were considered possessing a lower resistance to disease and underweight as a result of an inadequate wartime diet. ${ }^{31}$

When Hoover and his team arrived at the London airport on April 4, the exPresident was asked to deliver an address the next day to the "Emergency Conference on European Food Supplies," consisting of twenty-two countries summoned by the British Government. Hoover largely stressed the difficulty for children affected by the global famine, noting that the members of the Conference acknowledged that the next few months were a critical period before the next harvest. Though the situation would be helped for a time at that juncture, Hoover asserted that "world food problems are by no means ended..."32

Food supply conditions in Great Britain were rather favorable, as the nation had amassed approximately a million tons of food reserves, double the amount of its prewar

\footnotetext{
${ }^{29}$ Hoover, "Finland, Sweden, and Norway, 150-151.

${ }^{30}$ Ibid, 151.

${ }^{31}$ Maurice Pate, "The Children Are Hungry," Health and Child Care-Norway, April 4, 1946, Report from the Famine Emergency Committee, U.S. Department of Agriculture, 4.

${ }^{32}$ Herbert Hoover, "Great Britain," An American Epic, Volume IV, 154.
} 
capacity. Hoover recommended that as a result Great Britain could viably reduce reserves to prewar levels to help alleviate hunger needs in India and other locations. ${ }^{33}$ During a meeting with British Prime Minister Clement R. Atlee, Hoover suggested that the British assist less powerful nations in Europe in their efforts against further communist influences, mentioning Finland and when feasible, Poland and Czechoslovakia. To help sustain human freedom, he insisted, those areas were the places to begin. ${ }^{34}$

Returning to Belgium on April 6, where he had assumed his management of the CRB almost thirty-two years earlier, Hoover met the American Ambassador, Admiral Alan G. Kirk, who had arranged a discussion of food supply needs with Belgian Prime Minister Achille van Acker and other officials. As an assessment operation, consultation lasted for a comparatively shorter period of three days than the months of CRB relief work during the First World War. But the FEC group, comparing data from American officials in Belgium, and appealing for reduced food consumption, recommended that 60,000 tons of cereals be deployed each month from April through September. As the recovery of Belgian children appeared to be moving gradually, Pate advised the government to return to the same children's feeding program utilized during the First World War. ${ }^{35}$

In contrast to other European nations, assessments in The Netherlands and Denmark were far more positive. Though caloric intake had fallen to a low level during the last six months of the war, causing substantial deaths from starvation, the Dutch were

\footnotetext{
${ }^{33}$ Ibid, 157.

${ }^{34}$ Gibson, Diary Entry, April 5, 1946, Hugh Gibson Diaries, 102.

${ }^{35}$ Herbert Hoover, "Belgium, Holland, and Denmark," An American Epic, Volume IV, 159.
} 
in steady recovery with supplies they self-acquired ${ }^{36}$ Denmark had not resisted the Nazi invasion, and consequently was not ransacked as other nations had been, and remained in good condition with plenty of available resources. ${ }^{37}$

Nevertheless, the American, British, and French zones of Germany stood in much worse condition by the time the FEC arrived in Berlin on April 11. Through an interview with General Lucius D. Clay, serving as Deputy Military Governor for the American Zone, Hoover and the mission learned that all three Allied occupied zones were in worse food, clothing, medical care, and housing conditions than at the time of the surrender ten months earlier. Food rationing in all Allied zones, Clay elaborated, had already been cut down once and the General feared it would have to be reduced further. Hoover explained to Clay that "feeding the former enemy people required no debate, with me, since it must be done for many reasons," urging him to reinstate the 1,500 daily calorie ration. ${ }^{38}$

Hoover asserted that the predicament of the Germans rested primarily on "Hitler's wars of aggression and to his defeat amidst a Germany exhausted of supplies." $\mathrm{He}$ acknowledged that the imposition of disarmament and the Morgenthau Plan that aimed to eradicate Germany's capacity to instigate war through the abolition of its arms production and other military related industries, restrained any recovery of that nation. Officials, Hoover reiterated, needed to put grievances aside to avoid catastrophic starvation if civilization there were to continue. ${ }^{39}$

\footnotetext{
${ }^{36}$ Pate, "The Children Are Hungry," The Netherlands, April 9, 1946, 4.

${ }^{37}$ Hoover, "Belgium, Holland, and Denmark," 160-161.

${ }^{38}$ Herbert Hoover, "Germany and Austria," An American Epic, Volume IV, 162-163.

${ }^{39} \mathrm{Ibid}, 163$.
} 
Austria, Hoover felt, had been plundered by the Russians just as severely as had Germany. Though that nation had been sustained by the Allied occupying armies since the 1945 liberation, their "meager ration" supply was nearly at its end, and food management responsibilities had been given to UNNRA just before Hoover and the FEC arrived in Vienna on April 14. Hoover discovered that the health of Austrian children in Vienna and other industrial urban locations was one of the worst the team had experienced in Europe. Despite Austrian efforts to supply food, the daily allotment of 250 to 300 calories for each of the 90,000 affected children fell well below the recommended 1,500 calories. Although the team urged UNNRA to initiate a better children's food program, Hoover noted in An American Epic, the organization never responded. ${ }^{40}$ Swedish and Swiss authorities already had delivered supplies to Austria, but only could assist a few thousand at a time. Assorted other relief organizations, such as the American Red Cross, and others from Sweden, Switzerland, and Denmark also were contributing to "sporadic relief work for children in various parts of Austria." 41

A visit to Hungary was deemed unnecessary, as the Hungarians appeared to have an adequate food supply under Soviet occupation. But while in Yugoslavia, starting April 16, Hoover and the FEC assessed that the blend of war and internal disruptions in that nation had resulted in 120,000 "complete war orphans and 450,000 half-orphans." This existed alongside an average national mortality rate of twenty-one percent, twenty-five percent in Belgrade alone, with only less than one percent of the 40,000 children in that

\footnotetext{
${ }^{40}$ Ibid, 166-167.

${ }^{41}$ Pate, "The Children Are Hungry," Austria, April 15, 1946, 7.
} 
city receiving adequate food. Current UNNRA shipments, the team determined, only would feed the country until the next harvest. ${ }^{42}$

Pate indicated his admiration for the Yugoslavs as a "rugged people" and described the Greek people in the same way. The food organization within the Greek government was in good standing, he concluded. ${ }^{43}$ Still, Hoover learned from Greek officials of "the ineptitude of UNNRA" who had made serious errors in the food supply, delivering rations under the minimum endurance level. ${ }^{44}$

Hoover and the FEC team anticipated a bit of rest once they reached Cairo on April 18. The mission had previously learned the Egyptian food supply was sufficient for what Hoover described as "the very low standard of living." At the same time, the main goal for the stopover in Egypt had been to assess information about the food supply in other Arab states. Egyptian officials displayed great interest in the purpose of the FEC mission, as the team learned that they had designated around 40,000 tons of cereals for the Italians and Greeks. ${ }^{45}$

The ex-President also wanted to take the opportunity to communicate with President Truman. Though he had not spoken directly with Truman in the several weeks of the FEC mission, Hoover had delivered many addresses and held even more press conferences. By the conclusion of the trip a few weeks later, Hoover had delivered twenty-four addresses and held forty-two press conferences. Yet during a White House

\footnotetext{
${ }^{42}$ Herbert Hoover, "Hungary, Yugoslavia, Greece and Egypt," An American Epic, Volume IV, 169-170.

${ }^{43}$ Pate, The Children Are Hungry," Greece, April 17, 1946, 7.

${ }^{44}$ Hoover, "Hungary, Yugoslavia, Greece, and Egypt," 171.

${ }^{45} \mathrm{Ibid}, 172-173$.
} 
luncheon on April 17, Truman expressed to Julius Klein, now back in Washington, as well as to Secretary of Agriculture Clinton P. Anderson and Famine Emergency Committee Chairman Chester Davis, that he had been dissatisfied with the response of the American people to the efforts of Hoover and the FEC. The President conveyed the hope that Hoover could return to the United States and rally the conscience of the population from home. ${ }^{46}$

Hoover agreed with Truman's wish to further muster the American people to the famine relief needs, yet the ex-President felt that he would be of more value if he continued the mission abroad. He initially indicated this during a transatlantic phone call to Truman during the stop in Cairo. ${ }^{47}$ The next day Hoover cabled the President, stressing the necessity for the FEC to travel to India, China, and Japan to gain a more complete perspective on the entire famine problem. The need in Europe could not be separated from those of the Far East, he insisted. ${ }^{48}$

That same evening Truman delivered an address through all four U.S. radio networks and via shortwave radio to the rest of the globe. ${ }^{49}$ The President reiterated the urgent need to help the millions of starving people worldwide, underscoring the "high responsibility, as Americans, to go to their rescue." He reviewed the charge of Hoover and the FEC team, referring to the scenarios the mission had relayed about the overall

\footnotetext{
${ }^{46}$ Timothy Walsh and Dwight M. Miller ed., Herbert Hoover and Harry S. Truman: A Documentary History (Worland: High Plains Publishing Company, 1992), 72.

${ }^{47}$ Ibid, 73.

${ }^{48}$ Herbert Hoover, Telegram from Herbert Hoover to Harry S. Truman, April 19, 1946, A Documentary History, 73.

${ }^{49}$ Walsh and Miller, A Documentary History, 74.
} 
suffering of the affected people in the foreign nations. Truman continued to emphasize the need and obligation of U.S. citizens, through their spirit as Americans to help alleviate the famine, appealing to listeners "to sacrifice so that others may live," by consuming less so the millions would not die, through a mutual national effort. ${ }^{50}$

Hoover was allowed half of the thirty minute broadcast to deliver remarks from Cairo on the FEC mission. ${ }^{51}$ First he described the basic food needs of the 150 million affected people that the mission aimed to help, focusing on bread, fats, and calories. He then pleaded that "we can pull the world through this most dangerous crisis." Hoover emphasized that the salvation of life was not a global economic necessity, and more than "the sole path to order, to stability and to peace." It was an act of "the return to the lamp of compassion to the world," Hoover proclaimed, and "a part of the moral and spiritual reconstruction of the world." ${ }^{52}$

With the two leaders conveying the same viewpoints through the radio broadcast, Hoover and the FEC group proceeded to Iraq, an independent kingdom since 1932, on April 21 to secure around 400,000 tons of surplus dates and grain to be shipped to India. ${ }^{53}$ Once the team arrived in Karachi, Pakistan on April 22, however, they quickly discovered a serious issue entailing a delegation of Indian Nationalist leaders. While on a trip to Washington months earlier, the Indians claimed they had received a promise from the U.S. State Department of a four million ton cereal shipment and 500,000 ton

\footnotetext{
${ }^{50}$ Harry S. Truman, Truman Radio Address, Washington D.C., April 9, 1946, A Documentary History, 7475.

${ }^{51}$ Walsh and Miller, A Documentary History, 76.

${ }^{52}$ Herbert Hoover, Radio Address from Cairo, Egypt, April 9, 1946, A Documentary History, 76-77.

${ }^{53}$ Hoover, "Iraq, India, Thailand, and the Philippines," An American Epic, Volume IV, 178.
} 
allocation of other foods, of which there was no record. Even if the claim were true, Hoover later recalled, the same amount would have fallen well below the minimum needs of the starving Indian people. ${ }^{54}$ The food shortfall in India, he well understood, was as critical as any in Europe, largely due to recent droughts, the suffering being particularly severe in rural areas. The size of the famine moved the Indian government to appeal for relief through at least November $1946 .{ }^{55}$

Witnessing the looting and destruction done in Thailand by wartime occupying Japanese forces, Hoover and the FEC nevertheless saw the kingdom as a potential source of rice to India and the Philippines. At the same time, the team observed transportation difficulties in the nation and the fact that British Treasury authorities in London had been demanding rice supplies as "reparations" from Thailand for war damages inflicted on them during Thai aggression towards Great Britain after 1941. Yet eventually half of the Thai rice surplus would be shipped to India and the Malay States. ${ }^{56}$ As rice stocks in the Philippines were considered substantial enough to supply that nation into the next harvest, Hoover and the FEC suggested to British officials the exchange of U.S. army trucks for some of the rice surplus in Thailand and its shipment to India, in place of the preferred reparations. ${ }^{57}$

\footnotetext{
${ }^{54}$ Ibid, 150.

${ }^{55}$ Herbert Hoover and D.A. Fitzgerald, Cable Message of Hoover Mission Sent From Bangkok, Thailand to Secretary of Agriculture Clinton Anderson and Famine Emergency Chairman Chester Davis, Washington D.C.. April 27, 1946, p.1, Herbert Hoover Presidential Library and Museum, Famine Emergency Committee File, Cables: Miscellaneous, Box 147.

${ }^{56}$ Hoover, "Iraq, India, Thailand, and the Philippines," 185-186.

${ }^{57}$ Ibid, 187.
} 
When the FEC arrived in Shanghai on April 30, they learned that about 200,000 tons of cereals there, designated for relief supplies, had been already sold to speculators, constituting a "gigantic corruption going on in UNNRA." After meeting with both President Chiang Kai-shek and General George C. Marshall, the special envoy of President Truman in China, on May 3, Hoover and his team took note of the known food supply as well as the political and transportation situtation. Noting that Marshall "was endeavoring to amalgamate the communist government in the North under Mao Tse-tung with the nationalist government in the South under Chiang Kai-shek," Hoover took the position that it definitely was not a part of his and the FEC mission to "appear even tacitly to agree with the General." 58

After the FEC had conducted the assessment of food needs in China, Hoover issued a press statement that the need there was "enormous." Due to the previous eight years of destruction, drought and flooding, he noted, the requirements were beyond accurate estimation. Starvation and epidemics had already ravaged the interior regions and were progressing, he warned. The FEC responded with 200,000 tons of foods to be delivered between May and September. ${ }^{59}$

During the assessment in South Korea, Dr. Fitzgerald organized a program of 110,000 tons of food supply for the subsequent five months, while Hoover and the FEC recognized that food difficulties and other problems centered on the threat of invasion

\footnotetext{
${ }^{58}$ Herbert Hoover, "China, Korea, Japan, and Our Return Home." An American Epic, Volume IV, 188-189. ${ }^{59}$ Herbert Hoover, Press Conference Remarks, May 3, 1946, Shanghai, China, cited in An American Epic, Volume IV, 190.
} 
from Communist North Korea. ${ }^{60}$ Yet these circumstances paled in comparison to the "mass starvation on a gigantic scale" they confronted on their tour of Japan beginning May 5. Hoover insisted that massive imports through the Combined Food Board had to be undertaken for Japan to prevent massive death rates, likening the alternative to be similar to the German Buchenwald and Belsen concentration camps. Hoover believed that Americans would have to absorb the reality of the food needed to be provided for Japan. $^{61}$

Once the FEC mission had returned to the United States, Hoover wrote to Truman on May 13. This initial report was largely statistical, and related the minimum food needs of the affected nations and how the FEC had attempted to present the American "point of view" on the extent of the famine. The ex-President pointed out one of the most dominant needs found in the twenty-two nations visited during the 35,000 mile expedition centered on wheat and rice. ${ }^{62}$ Truman expressed gratitude for the work of the FEC mission and asked Hoover to return again to the White House to further discuss the food relief issues on May $16 .^{63}$

Though the meeting that day had been intended to discuss food relief, the subject of the Soviet Union's opposition to participating in UNNRA operations dominated the conversation. ${ }^{64}$ Truman shared the difficulties he had experienced with the Russians. Hoover responded that the only way to react to Moscow was with "a truculent spirit," as

\footnotetext{
${ }^{60}$ Hoover, “China, Korea, Japan, and Our Return Home,” 190-191.

${ }^{61}$ Ibid. 192-193.

${ }^{62}$ Herbert Hoover, Letter to Truman, May 13, 1946, Washington D.C., A Documentary History, 81.

${ }^{63}$ Harry S. Truman, Letter to Hoover, May 15, 1946, Washington D.C., A Documentary History, 83.

${ }^{64}$ Walsh and Miller, A Documentary History, 84.
} 
the Soviets had treated the United States in the same manner. Although Hoover believed minimum global food supplies could be met without Soviet help, however, he reiterated that their assistance would greatly alleviate the crisis. ${ }^{65}$

In another radio address, this time from Chicago on May 17, Hoover reemphasized the need for American food conservation, while reminding his audience that the "Four Horsemen of the Apocalypse," "War, Famine, Pestilence, and Death," with the exception of war, were still present over the globe. ${ }^{66}$ Noting that more than $800,000,000$ people across the world were still in danger of famine, Hoover explained that he had been asked by the President to undertake a food relief mission to Latin America in the coming days. $^{67}$

Hoover and the FEC crews left Washington on May 25th and landed in Mexico City the next day. It became quickly apparent that Mexico could not provide any surplus food to other nations while one third of its population lived in poverty but was willing to work with Argentina for food assistance. ${ }^{68}$ Panama did not require food relief assistance, while Colombia, much like Mexico, had little surplus food to export. Meanwhile, when the government of Ecuador stated that it could export 32,000 tons of rice, but at double the world price, Hoover responded that the mission was not buying the rice, but would offer the commodity to foreign markets. ${ }^{69}$ Hoover found Peru to be "in an economic

${ }^{65}$ Herbert Hoover, Hoover Notes of Meeting With Truman, May 16, 1946, A Documentary History, 84-84.

${ }^{66}$ Herbert Hoover, Radio Address, May 17, 1946, Chicago, A Documentary History, 86.

${ }^{67}$ Ibid, 87-88.

${ }^{68}$ Herbert Hoover, "Mexico, Panama, Colombia, Ecuador, Peru, and Chile," An American Epic, Volume IV, 203, 205-206; Herbert Hoover, Herbert Hoover Diary Entry, May 26-28, 1946, Mexico City, p.2, Herbert Hoover Presidential Library and Museum, Famine Emergency Committee File-Herbert Hoover Diaries, South American Trip, Box 148.

${ }^{69}$ Hoover, "Mexico, Panama, Colombia, Peru, and Chile," 206-207. 
mess," because inflation had restricted imports and created a strict program of food consumption. In contrast, Chile operated under nearly total self-sufficiency, halting all food imports during certain months of the year while still accomplishing to export a small amount of commodities. ${ }^{70}$

Among the largest objectives of the FEC mission was a visit to Argentina to secure food supplies for export to famine stricken nations. Newspapers in Buenos Aires were crowded with stories of Moscow and Russia, giving strong indication that the nation was leaning towards recognition of the Communist Soviet Union. ${ }^{71}$ Hoover indicates that American Ambassador George Messersmith had been reluctant to arrange a meeting with Argentinian President Juan Perón, whose election and leadership the U.S. State Department had opposed. Although Perón remained cordial to the party, he noted that Argentine gold reserves and other assets were still impounded by the Federal Reserve and other U.S banks. Unaware of these restrictions. Hoover asked Truman of his knowledge of these matters when he returned to Washington several weeks later. Once Truman called the State Department for an explanation, he authorized the lifting of the restraints on Argentina. ${ }^{72}$

Four other visits proved fruitful. Uruguay agreed to make a small amount of food available for export. Brazil, which had already been exporting 100,00 tons of rice and the same amount in corn in collaboration with the Combined Food Board while conducting a

\footnotetext{
${ }^{70}$ Ibid, 209.

${ }^{71}$ Mason, Dear Julius Letters, June 11, 1946, En route from Buenos Aires to Montevideo, p.1, Famine Emergency Committee File, Herbert Hoover Presidential Library and Museum, Box 147.

${ }^{72}$ Herbert Hoover, "The Argentine, Uruguay, Brazil, Venezuela, and Cuba," An American Epic, Volume IV, 210-214.
} 
successful domestic food conservation program, agreed to suspend wheat imports from Argentina and to aim supplies towards famine affected nations. Venezuela agreed to curtail its import of five thousand tons of food per month from the United States, while Cuba agreed to export any available surplus sugar with a promise to reduce flour imports from the United States. ${ }^{73}$

Once Hoover and the FEC returned to Washington on June 19, the mission had travelled to thirty-eight nations in fifty-seven days. Meeting with Truman again the next day, Hoover explained the situation in Argentina, while informing the President of his conclusion that food supplies would prevent starvation for every area the FEC visited except China. ${ }^{74}$ Nevertheless, the ex-President expressed to a friend a few days after his return, that though the mission had been "exciting" it was also "exhausting" and he wanted to rest. ${ }^{75}$

Nearly five months passed when Truman wrote to Hoover providing him details of the improved grain supply, both domestically and for export to famine stricken nations. The President specified that the situation during the fall of 1946 was much improved in contrast to the dilemmas that he and Hoover had faced the previous winter. Truman once again thanked the ex-President for providing a "real service for humanity."76 "I am of course available for any service I can properly perform," Hoover replied, while offering a supplemental list of recommendations for additional food relief

\footnotetext{
${ }^{73}$ Ibid, 214-217.

${ }^{74}$ Herbert Hoover, Notes on Meeting With Truman, June 20, 1946, Washington D.C., A Documentary History, 90.

${ }^{75}$ Walsh and Miller, A Documentary History, 90.

${ }^{76}$ Harry S. Truman, Letter from Truman to Hoover, November 29, 1946, A Documentary History, 91.
} 
efficiency that included relations with international governments regarding food supplies, an account of his experience with UNNRA, and thoughts on U.S. contributions to United Nations foreign recovery programs. ${ }^{77}$

Truman would take Hoover up on his offer when he summoned the ex-President in January 1947 to go back to Germany and deal with food supply issues occurring as a result of the merger of the American, French, and British Zones. The President also was concerned about how the food conditions in the British zone could affect U.S. interests. ${ }^{78}$ Secretary of War Robert P. Patterson had already phoned Hoover on January 5, nearly two weeks prior to the President's written request, asking him to go to both Germany and Austria because of a "very serious crisis in food supplies." Hoover was doubtful about accepting the mission, wanting a written request from Truman, and cautious about becoming involved in the economic and political policies of the U.S. government in the two areas, while assessing the hunger organization issues. Yet he would not refuse to undertake the task if the purposes of the mission were broadened to include not only the American and British zones, but the French zone as well. ${ }^{79}$ Just before leaving the United States with some members of the FEC group of 1946 and a few others, Hoover prepared another list of recommendations of food relief plans and submitted the report to the President. $^{80}$

\footnotetext{
${ }^{77}$ Herbert Hoover, Letter from Hoover to Truman, December 3, 1946, A Documentary History, 93.

${ }^{78}$ Harry S. Truman, Letter from Truman to Hoover, January 18, 1947. A Documentary History, 98.

${ }^{79}$ Herbert Hoover, "The Food Situation in Germany," An American Epic, Volume IV, 225.

${ }^{80}$ Ibid, 227-229.
} 
Once Hoover had undertaken a survey of the conditions in both Germany and Austria he complied a report of the conditions he felt were inhibiting improvement and recovery. He reiterated, much as he did during the visit in 1946, how the despair of the German people was based on Hitler's generating of war as well as the "vengeance of the Morgenthau Plan." Adding to this, Hoover pointed out, the resources available at the time of surrender had been diluted by reparations, forcing the population into a dependence upon the Allied occupation armies. ${ }^{81}$

A major increase in population also had become a factor, due to the eviction of German peoples from Russian, Polish, Czechoslovakian, Hungarian, and Austrian regions, raising the population of Western Germany to around nine million beyond 1939 levels. Housing and coal shortages, Hoover surmised, contributed as well, alongside the loss of prewar agricultural land to Russia and Poland. An absence in vital agricultural resources such as fertilizers, seed, equipment, and labor limited food production in both the American and British Zones to sixty-five percent of prewar yields. On top of that, an abysmal winter had frozen canals and interfered with rail transportation, multiplying the difficulties of distributing rations. ${ }^{82}$

In a lengthy outline Hoover proposed to increase ration amounts, yet he realized that it would cause an increase in tax burdens for both the United States and Great Britain. Hoover advised refinement of food programs to feed children and increase the rations for adults beyond 1,550 daily calories. Thorough, more efficient organization of

\footnotetext{
${ }^{81}$ Ibid, 230.

${ }^{82}$ Ibid, 231-233.
} 
feeding systems and utilizing Allied Army rations would assist in the recovery. Hoover also called for further reliance on food and collateral relief imports, using German exports to help pay for them. This could be done, he recommended, by dividing foreign trade into two categories. The first would be imports of food, fertilizers, and petroleum products for civilians funded by both the United States and Great Britain while the second would fall under the "Joint Export-Import Agency" that regulated raw material imports and exports of German resources. Added to this, Hoover believed, was the need for Germany to repay both the United States and Great Britain before reparations were ever given to any other nations. ${ }^{83}$

"If Western Civilization is to survive in Europe, it must also survive in Germany," Hoover stated in the conclusion of his memorandum. "And it must be built into a cooperative member of that civilization. That indeed is the hope of any lasting peace."

"After all, our flag flies over these people. That flag means something besides military power." ${ }^{\prime 84}$

Confidence and faith in the potential of the American people is apparent in the recommendations Hoover offers for comprehensive food relief. Assessing the food needs in thirty-eight nations, the former President recognized the needs of other people aside from political differences. For his part, President, Truman faced political obligations involving the future of the United States and its relationship to other nations after a world-wide war, but like Hoover, knew well of the immediate need to relieve the famine

\footnotetext{
${ }^{83}$ Ibid, 235-241.
}

${ }^{84} \mathrm{Ibid}, 243$. 
stricken peoples. The nearly two month trip had been intensely busy for Hoover and the FEC team, filled with constant data collection, meetings, diplomatic encounters, heart rendering scenes of destruction, and constant movement on both the ground and in the air. Yet Hoover and the FEC group had indeed accomplished what Truman and the administration hoped for. The FEC had helped to provide relief of the largest famine in global history, while simultaneously strengthening the image of the United States and expanding the bond between the current and former occupant of the White House. 


\section{Chapter 4}

Beyond the Mission

The conclusion of Herbert Hoover and the FEC group's global famine relief survey did not mark the end to the growing connection between the ex-President and Harry Truman. Their two-year plus bond had already been nurtured through common understandings as presidents, and mutual exchanges and the advice of experience from a former President to a serving one as well as the shared goal of combating the danger of global, post-war famine in the context of defending and proliferating American ideals and strategic interests.

Truman was pleased with what Hoover had accomplished in the assessment of the relief needs of Germany and Austria after reviewing the former president's two reports. He hoped they could positively influence the spring 1947 conference in Moscow between the U.S. Secretary of State and the British, French, and Soviet Foreign Ministers. ${ }^{1}$ A week earlier, the President had publicly expressed his satisfaction with the FEC mission and his appreciation of the efforts of the American people in helping feed millions of people worldwide. Although Truman conveyed confidence that American citizens were committed to continuing "the policy of sharing out of our abundance with those in dire

\footnotetext{
${ }^{1}$ Harry S. Truman, Letter to Herbert Hoover, March 11, 1947, Papers of Herbert Hoover, Joint Project of Harry S. Truman and Herbert Hoover Presidential Libraries site, www.trumanlibrary.org, 1.
} 
need," however, he warned that the hunger needs had not disappeared although they were being confronted. ${ }^{2}$

After another meeting with Truman on March 12, Hoover sent a third and final report on the $18^{\text {th }}$ elaborating on his views on supporting and reviving German industry to encourage "stability and peace in Europe." Hoover believed that regardless of past U.S. policies, German industries needed to be free with sufficient regulation to avoid recurrent "militarism." This meant the cessation of the destruction of manufacturing resources, such as what was proposed within the Morgenthau Plan, a proposal conceived by the U.S. Treasury Secretary Henry Morgenthau Jr. for the eradication of Germany's arms industry to prevent that nation from potentially instigating war in the future and opposing foreign government ownership of enterprises such as those executed in the Soviet sphere of East Germany. Hoover insisted that the Ruhr and Rhineland regions should not fall under separate governments in order to maximize the production of coal and other exports. ${ }^{3}$ Truman agreed with the need to address economic issues in Germany, pointing out to Hoover in a letter that he had used the Potsdam Conference to emphasize the need for freedom of commodity transportation along the Rhine and Danube rivers. ${ }^{4}$

Despite such an agreement, Hoover and Truman had substantial disagreements on relief policy. Earlier that February a "relief for war-devastated countries" bill, HJ Res

\footnotetext{
${ }^{2}$ Harry S. Truman, Statement to Public About Continuing Famine Conditions in Europe, February 28, 1947, Papers of Harry S. Truman, President's Secretary's Files, Joint Project of Harry S. Truman and Herbert Hoover Presidential Libraries site, www.trumanlibrary.org, 2.

${ }^{3}$ Herbert Hoover, Report to Harry S. Truman on Germany and Austria, March 18, 1947, Herbert Hoover and Harry S. Truman: A Documentary History, edited by Timothy Walch and Dwight M. Miller (Worland: High Plains Publishing, 1992), 107-108.

${ }^{4}$ Harry S. Truman, Letter to Herbert Hoover, March 24, 1947, A Documentary History, 109.
} 
153 , sanctioning an estimated $\$ 350$ million in relief for nations destroyed by war, had come up for debate in Congress. Truman had asked for the legislation during an address to remind Congress that the United Nations Relief and Recovery Administration (UNNRA) operations were nearing their conclusion and some nations severely affected by the war were still in need of assistance. The bill did not name specific countries to be relieved in its summary yet referenced Austria, Greece, Italy, Hungary, Poland, and China as prime targets for funding. At the same time, the measure stipulated that relief funds were to be sanctioned as gifts rather than loans. ${ }^{5}$

Hoover used the March meeting with Truman to relay his concerns over the bill and proposed several amendments with stronger controls over its expenditures. He sent the same list of changes to Representative Charles Eaton, Republican chair of the House Foreign Affairs Committee ${ }^{6}$ Hoover wanted relief to only come from U.S. "products," to be limited to food, seed, fertilizers, and medicine; to exclude any "obligation or promise" beyond month to month deliveries; and to stipulate that relief only be administered under U.S. supervision. Beyond this Hoover indicated that no relief be given to nations undertaking commercial exports of food and relief supplies. He also specified that nations receiving relief needed to set a date of repayment that would take priority over reparation payments, that any agricultural surplus should be designated towards repayments, and that any Administer of Relief needed to be designated under the jurisdiction of the Secretary of Agriculture. Concluding his suggestions, Hoover proposed to authorize the

${ }^{5}$ Congressional Quarterly. III (April 9, 1947), 257.

${ }^{6}$ Timothy Walch and Dwight M. Miller, A Documentary History, 106. 
President to transfer an amount from the expenditure equal to $57 \%$ of any fund raised by the United Nations for the special feeding of children," but not to exceed \$50 million. ${ }^{7}$

The ex-president had already made statements of support for the bill to the Foreign Relations Committee in February, emphasizing American support for Germany, Japan and Korea. He also indicated that the UN Refugee Organization and child-feeding program should be a prime focus of financial support. At the same time, Hoover reiterated the need to aim support towards the recovery of Germany and Austria, although relief for those nations could be held to the minimal amount needed to improve health and productivity, thereby not overburdening the American taxpayer. ${ }^{8}$

Noting his proposal of "aid to the United Nations project for the special feeding of subnormal children," Hoover argued that the plan would relieve some of the burden of children's health care within the upcoming bill. He relayed a list of suggested amendments to Truman several days later. A large part of his thinking on these matters centered on not overtaxing the American people to reach relief goals, while emphasizing the need to attain "efficiency and economy" in the recovery and restoration process "of the world and in the promotion of fundamental freedom and peace." Hoover acknowledged that it was essentially impossible for anyone to estimate the long term future of famine stricken nations beyond a single year, and suggested some kind of provision for the period beyond the upcoming harvest. A massive global shortage of food

\footnotetext{
${ }^{7}$ Herbert Hoover, Letter from Hoover to Harry S. Truman, March 12, 1947, A Documentary History, 106107.

${ }^{8}$ Herbert Hoover, "On Relief Assistance to Countries Devastated by War: Statement Before Committee on Foreign Affairs, House of Representatives," February 28, 1947, in Addresses Upon the American Road: 1945-1948 (New York: D. Van Nostrand Company, Inc., 1949), 286-287.
} 
supply still existed, Hoover insisted, reinforcing the reality of inaccurate estimates of food supply and distribution encountered during the FEC missions. ${ }^{9}$

Truman felt that he needed additional input about Hoover's thoughts, and asked his aide Charles Murphy for his perspective. ${ }^{10}$ Murphy reminded the President that one of Hoover's aims was to have the bill designate money toward the specific feeding of children. He indicated that he learned from State Department official Colonel Tyler Wood that any special program utilized to feed children would be funded by public or private contributions to accomplish the same purpose. Murphy also warned that moving any part the $\$ 350$ million allocated in the bill to the management of the United Nations "would be a grave mistake," as the whole amount had been intended to afford a minimal food supply to the nations in need, and the relief of children needed to be added to the amount rather than serve as an integral part. In reaction to State Department views, the Foreign Relations Committee rejected Hoover's amendment regarding the funding of children's food relief. ${ }^{11}$

Hoover, for his part, did not become discouraged by the defeat of this portion of his recommendations. At the same time, he pushed for tighter regulations on how the allocations would be spent. Wood discussed these ideas with Hoover, and listened to any of the ex-President's additional concerns later that same week. ${ }^{12}$ Yet administration officials adamantly opposed Hoover's recommendations about German and Austrian

\footnotetext{
${ }^{9}$ Ibid, 287-293.

${ }^{10}$ Walch and Miller, A Documentary History, 106.

${ }^{11}$ Charles Murphy, Memorandum to President Truman, March 24, 1947, A Documentary History, 110-111.

${ }^{12}$ Walch and Miller, A Documentary History, 111; Herbert Hoover, Letter to Harry S. Truman, March 29, 1947, A Documentary History, 111.
} 
recovery. Former U.S. representative on the Allied commission on Reparations Edwin W. Pauley voiced objections to nearly all of Hoover's proposals. Recognizing the "patriotic spirit with which the former President is serving his country, and with full respect for his capabilities," Pauley cautioned of the dangers in implementing the recommendations, particularly concerning German industrial recovery. Acknowledging Hoover's engineering experience Pauley admitted that the proposed pace of recovery could be faster than the one agreed to at the Potsdam Conference. Yet Pauley likened Hoover's proposal to putting people in the position of slaves to accomplish production goals, paralleling the process to U.S. mill workers of the nineteenth century. The recommendations, he concluded, incorporated a dangerous and unattainable goal. ${ }^{13}$

Truman aide John R. Steelman wholeheartedly agreed with Pauley, asserting that Hoover's proposals contradicted the commitments made by the American government at the Second Quebec Conference in 1944 between the United States and Great Britain, regarding the Allied occupation of Germany, the Morgenthau Plan, and continued U.S. Lend-Lease aid, as well as the results of the Potsdam Conference. Steelman feared that if Hoover's recommendations were followed it would allow Germany the capacity to build up another military force, as well as creating a dependence to that nation from other European countries through the rise in industry. For that reason, he supported economic controls in Germany rather than freeing up industry as Hoover had proposed. ${ }^{14}$

\footnotetext{
${ }^{13}$ Edwin W. Pauley, Letter from Pauley to President Truman, April 15, 1947, A Documentary History, 111. ${ }^{14}$ John R. Steelman, Memorandum to President Truman, April 17, 1947, 1-3, Herbert Hoover Presidential Library and Museum and Harry S. Truman Presidential Library and Museum Joint Project Site, www.trumanlibray.org.
} 
For his part, Truman had outlined his approach to the new U.S. role in the postwar world in his Truman Doctrine speech to Congress in March 1947. Ambiguous and unclear behavior and attitudes from the communist Soviet Union had raised concerns about U.S. relations with that nation. As Truman saw it, Soviet leader Joseph Stalin had rebuffed any friendship with the United States at the conclusion of the Second World War, only reacting with pressure on the west. ${ }^{15}$ In The Specter of Communism: The United States and the Origins of the Cold War, 1917- 1953 (1994), historian Melvyn P. Leffler points out that in 1946, during a speech at Westminster College in Fulton, Missouri, former British Prime Minister Winston Churchill declared that this same Soviet danger had created an "iron curtain" of tyranny across Eastern Europe. The line extended from the Adriatic to the Baltic Sea and included the eastern half of Germany, directly adjacent to the Allied occupied zones of West Germany. Leffler indicates that two close Truman aides, Clark Clifford and George Elsey, proclaimed that the Soviet leadership sought to eliminate any U.S. credibility in Europe and weaken the position. ${ }^{16}$

Leffler suggests that during 1946 fears of Soviet intimidation further emerged from the communist activities in Poland, Hungary, and Czechoslovakia; suppression of representative government in Finland and Austria; and unwillingness to disband the Red Army. Soviet desires for naval bases, air-transit rights, and petroleum concessions in Iran, alongside their rejection of the Acheson-Lilienthal Plan for the international sharing of nuclear energy to avoid nuclear war, topped by Stalin's rhetoric during a speech that year

\footnotetext{
${ }^{15}$ Robert H. Ferrell, Harry S. Truman: A Life (Columbia: University of Missouri Press, 1994), 247. ${ }^{16}$ Melvyn P. Leffler, The Specter of Communism: The United States and the Origins of the Cold War, 1917-1953 (New York: Hill and Wang, 1994), 53.
} 
warning Russians of a challenging path ahead and suggesting that another war was immanent due to the influence of capitalism, all added to U.S. apprehensions. ${ }^{17}$

Truman was particularly concerned with threats to Turkey and Greece from potential communist subversion and intimidation in 1947, leading the President to emphasize the need to financially support those nations. These threats stemmed from civil war in Greece supported by anti-British and anti-monarchist Yugoslav Communists, as well as Soviet pressures on Turkey to share control of the Dardanelles Straits, suggesting potential Soviet penetration of Mediterranean Sea lanes to Mid-east oil fields. $^{18}$

Truman expressed the need to aid Greece and Turkey in the name of democracy and resistance to the tyranny of "armed minorities." 19 For the President, each nation of the world faced a choice between following the free institution of "the majority," or the forced will of "the minority." Truman later recalled in his memoirs that he saw the statement as a "turning point in American policy," the viewpoint supporting the idea that wherever hostility occurred, "direct or indirect," and endangering peace, it concerned the safety of the United States. ${ }^{20}$

Leffler suggests that anti-Soviet American officials advocated for western European incorporation in order to encourage the formation of an "economic unit" to

\footnotetext{
${ }^{17}$ Ibid, 38-39, 52.

18 Ibid, 51, 67.

${ }^{19}$ Harry S. Truman, "The Truman Doctrine," March 1947, The U.S. Constitution and Other Writings (San Diego: Canterbury Classics, 2017), 372-373.

${ }^{20}$ Harry S. Truman, Memoirs by Harry S. Truman, Volume Two: Years of Trial and Hope (Garden City: Doubleday \& Company, 1956), 106.
} 
stimulate technological advancement and higher productivity. The "American design," he notes, was to produce a thriving, capitalist oriented, non-Communist Europe. ${ }^{21}$ Spurred by the Truman Doctrine and the need to use foreign aid to help contain the Soviet threat, the relief bill cleared the Foreign Relations Committee in April. Hoover nevertheless continued to push for amendments. The ex-President was contacted by Republican Senator Arthur Vandenberg to testify before the Senate Foreign Relations Committee on April 18. This gave Hoover the opportunity to meet again with Truman but he failed to gain support for his amendments. ${ }^{22}$ Hoover's awareness of the Administration's aversion to his proposals became more evident as he refused to stay in the vice-presidential residence at Blair House in Washington that May when John Taber, Republican chairman of the House Appropriations Committee, asked for a meeting to gain insight on the now estimated \$725 million proposed for relief. The ex-President felt that time in the Blair House did not give him the independence he needed during the stay and also suspected the building to be wired. ${ }^{23}$

Still, Hoover persisted in his views regarding U.S policy towards Germany and Japan and the $\$ 725$ million relief fund estimate. His perspective encompassed an American and British bi-zonal occupation of Germany while ultimately determining that only three options were possible with occupied Germany and Japan. The first involved western powers retreating and allowing "the conquered countries to drag the whole world to final chaos," The second would provide the people of Germany and Japan with a

\footnotetext{
${ }^{21}$ Leffler, The Specter of Communism, 114.

${ }^{22}$ Walch and Miller, A Documentary History, 114.

${ }^{23}$ Ibid, A Documentary History, 115; Edgar Rickard, Diary Entry, May 22, 1947, Hoover and Truman Library Joint Site, 1.
} 
subsistent level of food supply. Third, he suggested that the United States and Britain rid themselves of what hindered the progress of Germany and Japan's recovery, such as discontinuing the demolition of productive and peace-time industrial plants. ${ }^{24}$

Truman recalled in his memoirs that during debate over German supplies and steel production at the Potsdam Conference, Stalin supported the perspective that these factors were more important that food supply. Yet the President realized that Stalin was using the opportunity to gain access to the resources of the Ruhr basin. Subsequently, Truman indicated, Stalin began to advocate that the economic return of this industrial area should be made accessible to all of Germany, including the Soviet sphere. In turn, British Prime Minister Winston Churchill deemed that East German food supplies should be available to the whole of the German nation. Consequently Stalin retorted that Russia remained in worse condition than Britain due to the high level of human loss there during the war. ${ }^{25}$

Hoover was critical of Truman's performance at Potsdam as described in his memoir Freedom Betrayed: Herbert Hoover's Secret History of the Second World War and Its Aftermath (2011). The ex-President implied in later decades that Truman, through visionless statesmanship had acquiesced to the Soviet communist wishes, further bolstering the ratifications and annexations "of the previous surrenders to Stalin." The U.S. "reparations," as Hoover described what Truman had agreed to, resulted in a greater

\footnotetext{
${ }^{24}$ Herbert Hoover, Letter to John Taber, May 26, 1947, A Documentary History, 115-116.

${ }^{25}$ Harry S. Truman, Memoirs by Harry S. Truman: Volume One, Year of Decisions (Garden City: Doubleday \& Company, 1955.), 389.
} 
burden for the American taxpayer in the cost of relief for the Germans, impeding recovery there and elsewhere in Europe for many years. ${ }^{26}$

Ultimately the Soviets stated at Potsdam that they sought $\$ 20$ billion dollars in "reparations" from the United States, which Truman indicated was not going to happen, as he and the United States "would rather make grants for rehabilitation" to allies and "former enemies." As the FEC had completed its assessment and Hoover had submitted his famine relief recommendations by 1947, Truman relied on reports from Secretary of State George C. Marshall that suggested that Soviet self-interests had conflicted with U.S. efforts for peace during recent negotiations held in Moscow. Marshall argued that judging from strategies presented to him by the State Department, the most advisable path to the economic unity of Europe lay in cooperative and mutual solutions to its economic problems through U.S. aid. Truman agreed that this was an effective path to inspiring "hope and confidence" in the nations of Europe as a barrier against communism. $^{27}$

Any success in aiding Europe depended on the understanding of the American people of how and what the solutions should be in helping recovery, Marshall explained in his Marshall Plan Speech at Harvard University in June. He asserted that the needs of Europeans required the help of food and other essentials, largely from the United States, far beyond their current ability to afford. Supplemental aid was crucial, Marshall

\footnotetext{
${ }^{26}$ Herbert Hoover, Freedom Betrayed: Herbert Hoover's Secret History of the Second World War and Its Aftermath, ed. George H. Nash (Stanford: Hoover Institution Press, 2011), 881.

${ }^{27}$ Harry S. Truman, Memoirs by Harry S. Truman, Volume Two, 111-113.
} 
articulated, to avoid "economic, social and political deterioration of a very grave character." 28

Hoover expressed relief that he had not been selected to be a member of the advisory committee for the implementation of the project. Marshall had once suggested that both Hoover and statesman and financier Barnard Baruch serve as joint chairs. The ex-President thought that he would at least be asked for advice earlier in June but became irritated when he had yet to be approached. Hoover indicated to his friend Colonel John C. O'Laughlin that the Plan would require three times the amount of funding that the American people could ever provide, or be willing to give. O'Laughlin, a Washington insider, noted that part of the reasons for Hoover's not being selected had been the exPresident's earlier opposition to the Plan, along with objections to his recovery policies by key figures like Taber. At the same time, O'Laughlin stated that Marshall had once intended to incorporate "Hoover men" on the council to create difficulty for Hoover to criticize the Plan. In the end, both the President and Marshall wished to include committee members that would support the Plan rather than hold opposing views. ${ }^{29}$

Hoover had an additional opportunity to express his views when asked to be the first witness at the Senate Foreign Relations Committee hearing on the Marshall Plan, officially called the European Recovery Program. Yet he refused to take the invitation as the first speaker, writing to Senator Arthur Vandenburg that his concerns were that giving

\footnotetext{
${ }^{28}$ George C. Marshall, "The Marshall Plan Speech,"1947, The U.S. Constitution and Other Writings (San Diego: Canterbury Press, 2017), 379.

${ }^{29}$ Herbert Hoover, Letter to Colonel John C. Laughlin, June 23, 1947, A Documentary History, 119; Walsh and Miller, A Documentary History, 117-118.
} 
the power to one man, department, or government was detrimental to the conduct of policy that should rather be directed by a group, absent of partisan issues. Additionally, he foresaw that the United States would effectively be owing money to nations that provided resources for the other nations that required recovery. Hoover warned of the "illusion that scarcity and thus increasing inflation can be more than temporarily retarded by compulsory fixing of wages, prices, and rationing." Ultimately Hoover advocated for avoiding over-exporting and for "strong voluntary conservation measures" to lessen the burden on American citizens. ${ }^{30}$

Essentially, Hoover's responses to Truman's request to assess hunger needs across the globe between 1946 and 1947 substantiated the underlying desire of both men to provide relief within a distinct American approach to support democracy, freedom, and market economies. The work that Hoover and the FEC team had done laid a foundation for the foreign policy that Truman aimed to proliferate during this period of emerging Cold War. It was this goal that fundamentally brought the two Presidents together, and it remained the same purpose that sustained their bond and mutual vision.

Apart from discussions between Hoover and Truman over amendments to the relief for devastated countries bill, the two figures did not deliberate over the Marshall Plan. Yet the two men soon found themselves on a parallel path over government reorganization. During 1947, a proposal for a Commission on the Reorganization of the Executive Branch of Government, later termed the Hoover Commission, emerged as HR

\footnotetext{
${ }^{30}$ Walsh and Miller, A Documentary History, 122; Herbert Hoover, Memorandum to Senator Arthur H. Vandenburg, January 18, 1948, Addresses Upon the American Road, 1945-1948, 121-130.
} 
775. The bill was spearheaded by Republican Representative Clarence Brown of Ohio and Senator Henry Cabot Lodge of Massachusetts as a reaction to the perception of excessive government expansion during World War II.

Historians Timothy Walch and Dwiight M. Miller assert that Truman and several Democrats were apprehensive about the need to reorganize the executive branch, yet the bill passed both houses without debate with the help of Republican votes in June $1947 .{ }^{31}$ The panel was to investigate and make recommendations regarding economic needs, efficiency, and improved service in the federal agencies by eliminating waste, unnecessary duplication, and promoting consolidation and limits of executive functions and activities. ${ }^{32}$ It was to be comprised of twelve members, four appointed respectively by the President, Speaker of the House, and the Senate majority leader, and divided equally between the Republican and Democrat parties, public officials, and private citizens. Yet substantial funding for the commission became a worry early on for Brown and an unnamed appointee of the Speaker, who wanted the appropriation increased from $\$ 500,000$ to $\$ 1$ million. The House initially passed the addition but reversed its decision later in the day, despite greater support from House Democrats than Republican representatives. Facing his own concerns with the need to restructure the executive branch, Truman signed the bill on July 7, $1947 .{ }^{33}$

When Republican House Speaker Joseph W. Martin nominated and subsequently approached Hoover to join the Commission, the ex-President agreed to participate, but

\footnotetext{
${ }^{31}$ Walch and Miller, A Documentary History, 130.

${ }^{32}$ Congressional Quarterly, III (June, 1947), 488.

${ }^{33}$ Walch and Miller, A Documentary History, 130; Congressional Quarterly, 422.
} 
only as chair and Truman gladly approved of the option. Hoover had been aware, before he had made the second FEC mission to Germany and Austria in February 1947, that Congress had plans to create such an organization. But he was largely doubtful of its potential success as he realized the enormity of the task since he had attempted and failed to accomplish the same charge during his own administration. At the same time, Hoover assumed he would be working with a Republican president presuming that, as many from his party did, that Truman would not win re-election in $1948 .^{34}$

The 1948 Democratic presidential campaign did indeed involve a direct attack on the Republican Party and Hoover. Earlier that summer the President had sent a note of congratulations to Hoover on his speech at the Republican national convention, describing his words as "the utterance of a statesman." ${ }^{35}$ But in the progress of the race that fall, Truman assumed a political campaigning posture, making Great Depression references to the possible return of the "Hoover Cart," an analogy to the remains of an automobile being pulled by a mule under Republican rule. Going further during a speech in Boston, Truman accused Hoover of being an engineer who excelled at "running things backwards," and asserted that the Republican Party "would stop at nothing to gain power."36

Hoover did not publicly react to the President's onslaughts but continued with the task of leading the Commission. The former President expressed confidence about the

\footnotetext{
${ }^{34}$ Walsh and Miller, A Documentary History, 129.

${ }^{35}$ Harry S. Truman, Letter to Herbert Hoover, June 23, 1948, Hoover and Truman Library Joint Site, 1.

${ }^{36}$ Harry S. Truman, Presidential Campaign Address, Raleigh, North Carolina, October 19, 1948, 4-6; Presidential Campaign Address, Boston, Massachusetts, October 27, 1948, 4, Hoover and Truman Library Joint Site.
} 
task to the press after the first meeting in September, citing the bipartisan cooperation of both the Congress and the President. Politics needed to be left aside, he asserted, as the Commission had not been formed to pursue elements of misconduct, but to relieve the President of the voluminous issues brought upon him by the huge amount of “independent establishments" in the government. Congress, Hoover pointed out, had arranged for the report to be issued until after the 1948 election, aiding in the removal of political motives. ${ }^{37}$

In October 1947, Hoover issued a statement raising the subject of necessary boundaries in government to serve the development "of national life." The necessity to limit federal government functions, the statement declared, was not to threaten the functionality of state and local governments by potentially "overstepping" the "initiative and productivity of the people." 38 In making this assurance, Hoover communicated a similar ideology to the one he had described in The Challenge to Liberty (1934) thirteen years earlier. The book had elaborated on the potential downfalls and hindrances of an extensive bureaucracy, in a critique of his presidential successor Franklin D. Roosevelt and the New Deal. In describing his anxiety over overgrown government control, Hoover had argued that "The whole process of Regimentation with its enormous extension of

\footnotetext{
${ }^{37}$ Herbert Hoover, Statement to the Press, September 29, 1947, A Documentary History, 131-132. ${ }^{38}$ Herbert Hoover, "Policy Statement of the Commission on Organization of the Executive Branch of Government," Adopted on October 20, 1947, Addresses Upon the American Road: 1948-1950 (Stanford: Stanford University Press, 1951), 112.
} 
authority and its centralization in the Federal Government" undercut and damaged state authority and "thereby undermines one of the primary safeguards of liberty." 39

As work began on the Commission, associate James E. Webb, director of the Bureau of Budget, conveyed to Truman the need to support Hoover's leadership by refraining from "suggesting considerations, methods of study, and problems." Webb indicated that his future conversations with Hoover would center on gaining experienced staff for Commission work. Yet the President's only response was a handwritten note only saying "No commitments." 40

Truman's cautious attitude coincided with critics of Hoover's chairmanship of the body and his related abilities. Commission vice-chairman and Democrat Dean Acheson, based in part on John Steelman's recent meetings with Hoover, believed the ex-President did not possess the mind that he once did, while Press Secretary Charlie Ross remarked that in his opinion Hoover was not a healthy man. Committee member and Democrat James Rowe concurred with Acheson's suspicious view by April 1948, alleging that Hoover had intentions of pushing a particular agenda. Rowe was most concerned with Hoover's suggestion that no "task force reports should be submitted to the Commission until after the election," to prevent unwanted information disclosures and avoid the Commission becoming involved in partisan politics. It was Rowe's suspicion that Hoover deliberately had been trying to add what he wanted in Commission reports without giving

\footnotetext{
${ }^{39}$ Herbert Hoover, The Challenge to Liberty (West Branch: Herbert Hoover Presidential Library Association, Inc., 1989), 133.

40 James E. Webb, Memorandum to Harry S. Truman, Mid-October 1947, Hoover and Truman Library Joint Site, 1,3-4; Harry S. Truman, Response to James Webb, A Documentary History, 136.
} 
time for contradicting ideas, implying that a "careful study of Mr. Hoover's performance" signified that the ex-President always operated in that way. He further asserted that a bipartisan commission would not be of any use to the purposes of the commission. ${ }^{41}$

Although the election changed Hoover's assumption that he would be working with a Republican president and congressional majorities committed to undoing the New Deal, he quickly emphasized his wish to "work with the president not against him." Hoover stressed during weekly press conferences after the election that the Commission's goal was to establish a system that would provide help to the President who, he indicated at one point to a reporter, would determine the elements of that structure. Despite his earlier disparagement of the ex-President and other Republicans during the campaign, Truman assured Hoover of the importance of the time and experience that he and his "able colleagues" were contributing to the Commission, in the effort to confront the hinderances to efficiency in the Executive Branch. The President wrote to Hoover that "The task, as you and I have seen from our own experience, is to crystalize this general belief into concrete and wise proposals for action. ${ }^{, 42}$

Hoover seemed glad of Truman's affirmation as an indication that the advice from Webb had been of great help to the Commission's purpose. Truman in turn expressed his satisfaction from the positive reports from Webb regarding the directive's progress, asking Hoover for a face-to-face conversation for further discussion based on their

${ }^{41}$ Eban A. Ayers, Diary Entry, November 5, 1947, 1; James Rowe, Memorandum to Dean Acheson, April 16, 1948, A Documentary History, 137-139.

${ }^{42}$ Walch and Miler, A Documentary History, 141-142; Harry S. Truman, Letter to Herbert Hoover, November 12, 1948, Hoover and Truman Library Joint Site, 1. 
respective experience as government leaders ${ }^{43}$ But privately Hoover voiced to friends Edgar Rickard and Jerry Milbank that he was not optimistic after communicating with Truman. Despite the President's "nice personal notes," Hoover doubted that Truman would support his plans for restructuring the Executive Branch, particularly after the slander towards him during the Boston campaign speech. He confided to Rickard and Milbank that three of Truman's appointees to the Commission were attempting to avert comprehensive publication of the committee findings, and had only cooperated until that November. In spite of "giving all he has to this commission work," Rickard indicated, Hoover's pessimism "about most everything" continued through that December, doubtful that many of his recommendations would be put into law. ${ }^{44}$

During a meeting with Truman in January 1949, Hoover elaborated on the path and procedures of the Commission. The ex-President pointed out that the seventy agencies, currently beyond the President's capacity to supervise, should be reduced to at least twenty, despite the various objections that were already taking place. Another part of Hoover's recommendation advised to consolidate government construction works under the jurisdiction of the Department of the Interior, alongside authority over flood control, rivers harbors, and reclamations. Combining these factions, Hoover stated, provided improved technical ability, decreased competition and the prices of labor and materials, and advanced these departments towards more business oriented procedures. He came away from the meeting feeling that Truman agreed completely with the

\footnotetext{
${ }^{43}$ Herbert Hoover, Letter to Harry S. Truman, November 20, 1948, 1; Harry S. Truman, Letter to Herbert Hoover, November 26, 1948, 1, Hoover and Truman Library Joint Site.

${ }^{44}$ Edgar Rickard, Diary Entries, December 4, p.1, and December 29, 1948, p.1, A Documentary History.
} 
recommendations and wanted to offer any assistance towards their progress, prompting Hoover's openness to any suggestions from the President on Cabinet members that could offer support. $^{45}$

After Hoover delivered the first of twenty-one reports to Congress on February 5, the House received a continual flow of additional reports during the subsequent seven weeks. The first recommendation, however, discussed the number of earlier statements delivered to Congress that described changes endorsed by leading experts on natural resource, record management, national security, and other issues. A large part of Hoover's recommendation suggested that the authority of the President to "prepare and transmit" any designs for reorganization not be limited in any way. ${ }^{46}$

Following a telephone conversation and second meeting with Hoover later in the month regarding the addition of military based agencies to "Defense Services," however, Truman began to have second thoughts about his approval of departmental changes. The President had already signed the National Security Act of 1947, a major reorganization of the military and intelligence agencies combining the Departments of the Army and Navy into a national military establishment under the command of a Joint Chiefs of Staff and a civilian Secretary of Defense. The law also established the National Security Council and the Central Intelligence Agency, both accountable only to the President. Yet Truman saw himself in an awkward position over further government reorganization as Hoover had

\footnotetext{
${ }^{45}$ Herbert Hoover, Notes on Meeting with Harry S. Truman, January 7, 1949, A Documentary History, 146147.

${ }^{46}$ Walch and Miller, A Documentary History, 147; Herbert Hoover, Hoover Commission Report, February 5, 1949, Passage from "General Management of the Executive Branch: A Report to Congress" (Washington D.C., 1949) cited in A Documentary History, 147-149.
} 
sought his support before he had even reviewed the recommendations. First in Truman's mind was his apprehension over appearing to favor Hoover over the commissioners he had appointed. ${ }^{47}$

As Hoover persisted in seeking the President's support on reorganization, Senator Arthur Vandenberg alerted him to a possible defeat of the Commission's proposals through opposition from powerful Democratic congressional interests. Vandenberg suggested that the plan be split into smaller units, while Hoover pursued further Republican support. ${ }^{48} \mathrm{He}$ discussed the problem with Truman who anticipated that any issues could be smoothed out on the Senate floor while the ex-President felt that he could deal with Republican discontent. ${ }^{49}$

By May, Truman had begun to fall into agreement with Commission recommendations. He stated in an address to Congress that the "basic requirement" for effective management could only be accomplished through the President having the authority and resources provided him in the Constitution. Lacking this authority, Truman asserted, the President could not be held accountable or fulfill his Constitutional responsibilities." 50 The main points of the Report centered on the Executive Branch's lack of centralization, its use of too many agencies, and the President and department heads' lack of proper tools to implement policies. Additionally, the Commission asserted

\footnotetext{
${ }^{47}$ Herbert Hoover, Notes of a Telephone Call With Harry S. Truman, February 6, 1949, A Documentary History, 149-150; Hoover Notes of Meeting With Truman, February 9, 1949, 150-151; Walch and Miller, A Documentary History, 151.

${ }^{48}$ Walch and Miller, A Documentary History, 154.

${ }^{49}$ Herbert Hoover, Notes on Telephone Conversation Between Hoover and Harry S. Truman, April 7, 1949, Hoover and Truman Library Joint Site, 1.

${ }^{50}$ Harry S. Truman, Message to Congress, May 9, 1949, Hoover and Truman Library Joint Site, 1-2.
} 
that budgeting, accounting methods, record keeping, and purchasing procedures, including those by the Office of General Services, were inadequately organized. Reorganizing federal supply operations by establishing a Bureau of Federal Supply, and strengthening the authority of the Secretary of Defense in supply operations by amending the National Security Act were further suggestions. Streamlining personnel management needs, replacing the Department of Interior with a newly organized department, and the complete reorganization of the Veteran's Administration due to its huge annual expenditures, comprised other facets of the Report. ${ }^{51}$

Truman elaborated on his endorsement of Commission recommendations during a short ceremony where he received its final report. He reiterated his support for the recommendation that the administration of the Executive Branch be under the responsibility of the President and department heads. While the Commission had been cautious about putting dollar amounts on reorganization proposals, Truman asserted, demonstrations of the savings would emerge over time..$^{52}$

Through the remainder of 1949 and into 1950 public reaction to the Commission's reports and findings was mixed. A Citizens Committee For The Reorganization of the Executive Branch of the Government created as a follow-up and support group of the Commission chaired by Dr. Robert Johnson, president of Temple University, emerged in April 1949. Billing itself as a voluntary, nonpartisan body

51 The Hoover Commission Report on the Organization of the Executive Branch of the Government (New York: McGraw-Hill Book Company, Inc., 1949), 4-6, 98-104, 109-112, 267, 359.

${ }^{52}$ Harry S. Truman, Statement During Ceremony of Final Commission Report, May 26, 1949, Hoover and Truman Library Joint Site, 1-2. 
organized at Hoover's request, the group featured a Board comprised of agricultural, business, educational, labor, veterans, and women's group leaders. Its public pronouncements focused on annual taxpayer savings, and a desire to inform the public of the Commission's recommendations and procure its support. In explaining the motives of the Committee, Johnson proclaimed that it "will work to give President Truman and to Congress the encouragement of an informed public in modernizing the government." 53 The Committee championed the idea of "a blue print for a lasting government," that had achieved more in three and a half months than at any previous time in the nation's history, including savings between $\$ 1.25$ billion and $\$ 4$ billion. The Committee proclaimed that although "some battles have been won... Most of the War is still before us." 54

Others like Wisconsin Republican Senator Joseph McCarthy appealed to the President for quick action in implementing Commission recommendations. McCarthy pointed out that previous attempts to increase government efficiency extended back to the Andrew Jackson presidency but none had achieved the depth of the Hoover Commission. He indicated that the Senate had unanimously passed the reorganization bill, providing

\footnotetext{
53 "Board Named in Drive for Hoover Reforms," The New York Times, May 16, 1949, 12.;Register of the Citizens Committee for Reorganization of the Executive Branch of the Government Records, Online Archives of California, Stanford University, 2014; Willian G. Weart, "Group Set to Push Economies for U.S.: Dr. R.L. Johnson of Temple U. Heads Citizens' Committee to Back Hoover Projects," The New York Times, March 30, 1949, 2.

54 "Hoover Commission Inspires Many State Studies of Reforms," Committee Reporter, Newsletter, August-December 1949; Citizens Committee For the Reorganization of the Executive Branch of Government, Letter to William Hallam Tuck, November 15, 1949, 1; Robert Johnson, Chairman of Citizens Committee, Letter to William Hallam Tuck, September 16, 1949, 1, Herbert Hoover Presidential Library and Museum, William Hallam Tuck Papers, Citizens Committee for the Hoover Report File, Box 1. ;Citizens Committee for the Reorganization of the Executive Branch of the Government, Reorganization News: A Digest of News and Comment on the Progress of the Hoover Commission Report, October 1949, Herbert Hoover Library, William Hallam Tuck Papers, Box 1.
} 
the President with "almost unlimited power to clean house," despite objections from several government agencies. ${ }^{55}$

One of the largest public factions to voice opposition to the Hoover Commission was the American Legion. The Legion expressed strong concerns about the streamlining of the Veteran's Administration, alleging that the Hoover Commission could eliminate the full benefits to which veterans were entitled. Yet Armed Force magazine, a defender of veterans' interests, saw the Hoover Commission as an aid to curing the inefficiencies of the VA. The waste and disorganization the Commission found in the VA, it argued, was identical to problematic issues discovered four years earlier by former American Legion commander John Stelle, and still had not been addressed. An anonymous veteran commentary in The New York Times indicated that although the writer did not want any recommendations enacted, it was "at the height of absurdity" for the Legion to accuse the Hoover Commission of "plunging the knife" in the backs of service people. Additional criticism from The Washington Post and the Times-Herald called for the Legion to be fair and cease criticism of the Commission, as the onslaught appeared to be more of an American Legion “defense of its own power" rather than guarding veteran's rights. ${ }^{56}$

Hoover acknowledged that the recommendations of the Commission were "complex and controversial" but that the task force findings were grounded on facts and

\footnotetext{
55 Joseph R. McCarthy, "A Program for Putting Into Effect the Recommendations of the Hoover Commission on Reorganization of the Executive Branch of the Government," Speech in the United States Senate, June 13, 1949, Hebert Hoover Presidential Library and Museum, 3-4, William Hallam Tuck Papers, Hoover Commission (First) File, Box 1.

56 “Ox Goring," Armed Force, Vol. VI, No. 6, February 11, 1950, 1; "Veterans' Report," The New York Times, February 15, 1950; "Congress and the Legion," The Washington Post, February 4, 1950, "Play Fair, Legion” Times-Herald, February 18, 1950, Herbert Hoover Presidential Library and Museum, William Hallam Tuck Papers, Hoover Commission (First) File, Box 1.
} 
the needs of veterans and a product of the "sincere convictions" of the individuals who undertook the study. ${ }^{57} \mathrm{He}$ was happy with the support he received from the Citizen's Committee, but continued to be displeased with Truman's diluting of some of the reorganization plans when presenting them to Congress, sensing that the President was insincere in giving complete support through much of the process. Hoover indicated in a statement that Truman had presented twenty one Reorganization Plan variations of his own to Congress, sixteen of which passed, and "five missed," while the President adopted one Commission proposal concerning the Merchant Marine organization. Of the Commission's eighteen major recommendation's, Hoover pointed out, only four had passed, including the unification of the Armed Services, creation of the General Services Administration, the State Department reorganization, and "now the Merchant Marine reorganization." 58

But while Hoover disagreed with much of Truman's actions he still was satisfied with the progress of the Commission, and began to step away from involvement in government reorganization after mid-1950. The Citizen's Committee now took the place of the ex-President, pushing Congress for reforms and simultaneously impressing the Truman administration with its own efficiency. Meanwhile, the administration sought to persuade Committee leaders to support Truman's intended reforms. ${ }^{59}$

\footnotetext{
57 "Hoover Lauds the A.V.C. for Aid To His V.A. Plan," New York Herald Tribune, February 28, 1950, Herbert Hoover Presidential Library and Museum, William Hallam Tuck Papers, Hoover Commission (First) File, Box 1.

${ }^{58}$ Edgar Rickard, Diary Entries, December 14, 1949, March 16, 1950, A Documentary History, 176-177; Herbert Hoover, Hoover Statement, May 23, 1950, A Documentary History, 177-178.

${ }^{59}$ Walch and Miller, A Documentary History, 178.
} 
Once Truman left office after 1952, the President and Hoover "were on equal terms" in regards to the two both being former presidents. ${ }^{60}$ Yet Hoover was called on by Republican President Dwight D. Eisenhower to serve as one of the four presidential appointees for a Second Hoover Commission in July 1953 once Eisenhower signed the Ferguson-Brown bill. The new Commission had a far more conservative task than the first in its work toward "eliminating non-essential services, functions, and activities which are competitive with private enterprise," and departing from the requirement that an even number of Republicans and Democrats serve on the task force. The Commission held the power to subpoena witnesses and consider "recommending legislation and constitutional amendments." ${ }^{.61}$

When asked by Senator Clarence Brown, co-sponsor of the bill, about possible appointees to the Commission earlier that June, Hoover initially turned down the query because he was not satisfied with the choice of other members and their ambitions for "private enterprise." He told Brown, "Unless that Commission is set up under men who believe in it, certainly I want no part in it." Yet Hoover consented to join the Commission once Eisenhower wrote him a personal note asking him to be a member, as the President appeared to understand his views on the project. Hoover's concerns included his objection to federal power projects because of the estimated cost of $\$ 50$ billion for upcoming navigation, flood control, irrigation, and electric power undertakings planned at Eisenhower's request. The current economy could not absorb such endeavors, forcing

\footnotetext{
${ }^{60}$ Ibid, 211.

${ }^{61}$ Gary Dean Best, Herbert Hoover: The Postpresidential Years, 1933-1964, Volume Two (Stanford: Hoover Institution Press, 1983), 371-372.
} 
them into delay or postponement, Hoover insisted, pointing out that the purpose of the commission "must be to restore the vitality and responsibility of local government in the administration of these projects."

Despite such reservations, Hoover was appointed chair of the Commission at its first meeting in September 1953. He indicated in a press release that the First Commission had made 273 total recommendations to restructure the Executive Branch of the federal government, of which 122 were still uncompleted. Yet even though agency heads had been given autonomy in reorganization, many problems of inefficiency could not be solved within an individual unit because those same bureaus were fundamentally connected to others. The ex-President implied that the new Commission needed to “specialize in such fields," as accounting, budgeting, and personnel within a multi-agency context. Hoover insisted that the President continued to be inundated with numerous agencies that answered to him that lacked their own acceptable supervision. ${ }^{63}$ Accordingly, he seemed to suggest that the First Commission had not been comprehensive enough to cover the issues raised in a sprawling government that required additional scrutiny to help provide solutions, and move into an effective future.

The ex-President's cooperation with President Truman had not ended with the conclusion of the pivotal mission that assessed the food supply needs of a world ravaged by the world war. As the United States faced the ongoing need to assist the nations affected by the war and in need of recovery, the simultaneous communist threat emerging

${ }^{62}$ Ibid, 371-372.

${ }^{63} \mathrm{Ibid}, 374$. 
from the Soviet Union added to the challenges of national security and the preservation of democratic capitalism. Hoover played a concrete role in offering advice and advocating amendments to the legislation aimed at providing relief for the nations destroyed by the recent conflict. His goals focused on supporting peace, stability, and reconstruction in other nations, while Truman placed this agenda amid the widening menace of communism. The "Truman Doctrine" and Marshall Plan pursued this strategy through the long-term recovery of Europe, and building of a stronger connection between the United States and the Western world. While much of Hoover's own recommendations for recovery legislation went largely unheeded in the midst of political debate, his abilities had not been completely neglected. Truman still considered the importance of Hoover's experience as valuable, asking the ex-President to affectively reorganize the huge postwar executive bureaucracy. The bond between Hoover and Truman, although compromised by political differences, was strengthened and preserved by their common vision of providing help to those in need and demonstrating the American ideals they both advocated. 


\section{Conclusion}

Since President Harry S. Truman requested advice from Herbert Hoover on the global famine situation in 1945 and sent him and a group of the ex-President's colleagues across the world to survey conditions the next year, relations between the two figures were often politically and personally tentative. Yet as historians Timothy Walch and Dwight M. Miller indicate, since their first White House meeting in May 1945, both Hoover and Truman had connected through a mutual respect of the office and the heritage of the presidency, as well as for each other. ${ }^{1}$

Still, Hoover and Truman communicated very little in the period between January 1953 and October 1955. This changed when Truman asked Hoover to assist in raising funds for the Truman Presidential Library in Independence, Missouri after which both exPresidents corresponded frequently. In the duration between the initial fundraising and construction of the Library, Hoover discussed the results of the second Hoover Commission on "Meet the Press" in December 1956, taking care to commend Truman for his support of the first Commission. Evidence of the growing bond is seen in Truman's response to Hoover's comments. "I thought your statements on Meet the Press were excellent and I can’t tell you how very much I appreciated them,” Truman wrote. "I value your friendship very highly and am sure that you and I will continue in the same vein

\footnotetext{
${ }^{1}$ Herbert Hoover and Harry S. Truman: A Documentary History, ed. Timothy Walch and Dwight M. Miller (Worland: High Plains Publishing Company, 1992), 211.
} 
even though we may not agree all the time as to policy. I don't think a man has to make a personal matter out of things of that sort and I never did.",2

After other notes of thanks and appreciation between the two, Hoover expressed his thoughts on the Truman Library's contribution to the preservation of the historical record during the dedication in July 1957. "The inspiration and lessons of the upbuilding of our nation have received a real contribution through Mr. Truman's gift," Hoover reiterated during his address that day. ${ }^{3}$

"You do not know how very much I appreciated your kindness in coming to Independence on the sixth for the dedication of the library," Truman responded. The note was typical of the correspondence between the two ex-Presidents for the next several years, that included thanks for positive public remarks, "get well" wishes from Truman to Hoover after a gall bladder operation, discussions about political candidates, and annual birthday telegrams and letters. ${ }^{4}$

Upon attending the dedication of the Herbert Hoover Presidential Library and Museum in West Branch, Iowa on August 10, 1962, Truman delivered similar remarks to those that Hoover had made five years earlier. Along with describing his perspective on the uniqueness of the U.S. presidency, he soon mentioned the Famine Emergency Committee mission and Hoover's participation in the effort:

\footnotetext{
${ }^{2}$ Ibid, 211, 214; Harry S. Truman, Letter to Herbert Hoover, January 27, 1956, A Documentary History, 214.

${ }^{3}$ Herbert Hoover, Hoover Address at Harry S. Truman Presidential Library Dedication, July 6, 1957, $A$ Documentary History, 218-219.

${ }^{4}$ Walch and Miller, A Documentary History, 219-237; Herbert Hoover Presidential Library and Museum, Post-Presidential: Individual, Truman, 1962-Tuck, Box 240.
} 
I think the world of him, as I have said before. He did a job for me that nobody else in the world could have done, he kept millions of people from starving to death after the Second World War just as he did after the First World War for Woodrow Wilson, and when I asked him if he would be willing to do the job he never hesitated one minute, he said 'Yes Mr. President, I'll do it.' And he did a most wonderful job of keeping these people from starving, and what more can a man do ${ }^{5}$

Later in 1962, after an exchange of books between the ex-Presidents that included On Growing Up, a compilation of letters between Hoover and children during his career, and Truman Speaks, a collection of Truman's lectures at Columbia University, proof of the friendship became evident. After thanking Truman for the book Hoover acknowledged that "yours has been a friendship which has reached deeper into my life than you know:"

When you came to the White House within a month you opened the door to me to the only profession I knew, public service, and you undid some disgraceful action that had been taken in prior years...For all of this and your friendship, I am deeply grateful. ${ }^{6}$

Writing a eulogy eight months after Hoover's death at the age of ninety on October 20, 1964, Truman centered his tribute largely around their initial acquaintance, and the "higher calling" that moved Truman to invite him back into public service. "The meeting between him and me at the White House is now history," Truman noted. "His work in feeding the hungry expressed the care and generosity of all Americans,

\footnotetext{
${ }^{5}$ Harry S. Truman, Truman Remarks at Herbert Hoover Presidential Library and Museum Dedication, August 10, 1962, A Documentary History, 234-235.

${ }^{6}$ Walch and Miller, A Documentary History, 236; Herbert Hoover, Letter to Harry S. Truman, December 19, 1962, A Documentary History, 237.
} 
regardless of the political differences." "Briefly put, he was my friend and I was his," the former President concluded, a sentiment held until his death on December 26, $1972 .^{7}$

The friendship that Hoover and Truman ultimately formed had not been obvious at the start. Their initial introduction in May 1945 had been positive, purposeful and symbolic, as Truman brought Hoover back into the visible public sphere after years of reproach while seeking seasoned advice amid a looming global famine and emerging Communist threat. Yet both presidents were still on opposite sides of the political divide. Each possessed different paths of political experience as well, entering the governmental domain at dissimilar levels; Hoover as a top U.S. administrator and presidential Cabinet member, Truman a Mid-west county judge and senator, thrust into the presidency after mere weeks of assuming the Vice-Presidency. Individually, they pointed out the perceived deficiencies of one another in subsequent years, Hoover expressing, on more than one occasion, his lack of confidence in Truman as a leader not capable of comprehending vital issues, while the President later described his belief that the exPresident had not developed proper political experience when beginning so close to the top. ${ }^{8}$

Though both men still had many similarities in their backgrounds through a Midwestern heritage, Hoover did not fit into a typical politician's mold with his shy, rather sensitive, non-charismatic personality, while Truman relished the opportunity in the 1948

\footnotetext{
${ }^{7}$ Harry S. Truman, Truman Eulogy to Hoover, June 1965, A Documentary History, 239-240.

${ }^{8}$ Edgar Rickard, Diary entries, March 2 \& 13, 1946, A Documentary History, 68-69; Harry S. Truman Interview, October 21, 1959, Cited in Robert S. Ferrell, Harry S. Truman (Columbia: University of Missouri Press, 1994), 99.
} 
presidential election as a political foothold to criticize the Republican party and the exPresident's difficult presidency. ${ }^{9}$ Yet as they both served as U.S. Presidents, each realized the enormity of the office, a position of leadership with pivotal responsibilities with vast populations looking to them for national guidance.

A ravaged postwar world, and the U.S. place in it, ultimately brought the two men together. The Second World War had created severe food shortages, in both supply and the means of production, throughout Europe and into Asia. Truman, facing the job as a leader of the world's sole superpower and oldest democracy, realized that the United States could take the lead in alleviating the looming global famine. U.S. geopolitical interests in sustaining free market economies and stemming the spread of the Communist threat from the Soviet Union aligned with the President's humanitarian impulses. Truman and his advisors knew as well that Hoover had proven experience and ability in managing such a crisis during the First World War, and that the ex-President could be consulted for the routes by which the government might approach the challenge. Hoover would spend more than double the amount of years focusing on humanitarian aid after World War II than all his time in government or as an elected official. At the same time, he expressed his political opinions throughout his later decades, and the chasm of political ideology between Truman and him never completely eroded.

But it was far more than the respective histories and experiences of each, despite ideological dissimilarities, that bonded them in a mutual vision through the remainder of

${ }^{9}$ Bruno Cabanes, The Great War and the Origins of Humanitarianism, 1918-1924 (New York: Cambridge University Press, 2014), 208; Harry S. Truman, Presidential Campaign Address, Raleigh, North Carolina, October 19, 1948, 4-6; Presidential Campaign Address, Boston, Massachusetts, October 27, 1948, 4, Hoover and Truman Library Joint Site. 
their lives. While Truman asked Hoover for advice on the postwar global famine, and subsequently sent him and a team to assess those needs as an integral part of the Famine Emergency Committee (FEC), the mission was primarily a fulfillment of the exPresident's belief that humanitarian aid vitally supported world peace, security and longterm U.S. interests. Hoover had incessantly advocated a philosophy throughout his life that food supply ultimately produced far more national stability than did the implementation of military power and strength. Governments that pursued military might, rather than providing their own populations with secure, well managed food supplies, Hoover maintained, only faced the Four Horsemen of the Apocalypse: War, Famine, Pestilence, and Death. ${ }^{10}$

This philosophy coincided with Hoover's beliefs expressed in American Individualism about government's function in creating a base for a successful economic system. His convictions about the role of associationism, volunteerism, and cooperative individualism in sustaining moral, intellectual, and economic advancement and the public welfare rested on a foundation of creative, responsible leadership that Hoover identified with the universal applicability of the "American System." The ideal of striving for decentralized techno-corporate organization, socially responsible individualism, and democratic self-government would be sustained through an "associative" economy, where trade and professional associations worked with the federal government to promote efficient production and competition. This concept fell midway between socialism and capitalism, both of which would have debased Hoover's brand of

\footnotetext{
${ }^{10}$ Herbert Hoover, "World Famine Situation," Address Under Sponsorship of the Famine Emergency Committee, Sherman Hotel, Chicago, Illinois, May 17, 1946, Addresses Upon the American Road: 19451948 (New York: D. Van Nostrand Company, Inc., 1949), 221.
} 
American individualism and contradicted the volunteerism associated with his Quaker roots. ${ }^{11}$

It is important to note in this context that the purpose of the collaboration between the two men went beyond Truman's emphasis on the maintenance of U.S. influence in the world during the early Cold War. Indeed, the Truman Doctrine had conveyed the protection of democracy and the liberty of free peoples as a major motivation for preventing the spread of communism. Ambiguous pronouncements and simultaneous belligerency from the Soviet Union did create the need to guard the democratic freedoms espoused by the U.S. and its allies. Truman accepted this responsibility within the framework of U.S. geopolitical and economic interests during the postwar period. But the significance of Hoover and Truman working together in the FEC missions and their relationship went much farther.

Rather, as this research suggests, it was the overall merging of two ideologies into a much larger common purpose, as seen by both leaders, to maintain and ultimately proliferate peace, human potential, and long term global stability centered on a vision of American ideals of freedom, ability, and promise. In their view, American influence was intended to help other nations by lifting afflicted nations from destitution and assist them in pursuing a positive future.

Both men had to be aware that America was never a perfect land, with its major social and economic issues past and present. Hoover, moreover, had travelled extensively

\footnotetext{
${ }^{11}$ Herbert Hoover, American Individualism (West Branch: Herbert Hoover Presidential Library Association, Inc., 1922), 17, 22-23; Joan Hoff Wilson, Herbert Hoover: Forgotten Progressive (Prospect Heights: Waveland Press, 1975), 56-57.
} 
across the globe during his engineering career decades prior to the FEC mission, encountering diverse cultures and circumstances. Describing his impressions later in his memoirs, he related the observed qualities of each, expressing respect for their sovereignty at the same time. Any real critique had been aimed at the absurdity in the hegemonic oligarchy of Great Britain, pointing out that America never had the formal class divisions and "impenetrable stratifications" leaving masses of people in economic desolation. ${ }^{12}$ Moreover, he had witnessed firsthand the results of both world wars and what conflicting forms of government and peoples were capable of doing to one another.

Truman himself a World War I veteran, and a seasoned subject of financial and career highs and lows before his presidency, was well aware of the intricacies of politics, and at the same time, the potential of the liberties and principles that could be employed in the world. Being shaped by his past experiences and personal convictions, Truman as President simultaneously realized the threats to those liberties from communist and earlier fascist governments and his need as a leader of the capitalist democracies to contain that danger.

Despite the fact that Hoover was fundamentally a non-interventionist, Truman used the ex-President's experience and advice, confident of his abilities to assess the food supply needs of devastated nations and contribute to preserving the remaining free nations in a postwar world. Hoover may not have agreed with the long-term occupation of foreign nations, since his version of aid centered on propping up a nation and its people as a temporary form of assistance, allowing populations to endure and start again.

\footnotetext{
${ }^{12}$ Herbert Hoover, The Memoirs of Herbert Hoover: 1874-1920, Years of Adventure (New York: The Macmillan Company, 1961), 127.
} 
This perspective had been demonstrated several times through the Committee for Belgian Relief, the American Relief Administration, and later the FEC missions. Regardless of the form of government that may have persisted in those areas, humanity took the lead for Hoover. Underlying this was his ongoing belief in American principles and the example of optimism and hope that the United States might be able to provide to others.

Coupling this with the need to contain the Communist threat, Truman used Hoover's work with the FEC mission to launch both aid to shattered nations and peoples through U.S. resources to establish lasting stability and peace wherever he and the West could. Coinciding with Hoover's idea of relief, Truman sought not only aid to feed hungry populations but in the long-term help sustain free market systems in the affected areas. This support of capitalism by both Hoover and Truman was part of their vision of American potential, and the desire to create durable prosperity, making the support of free markets a major component of U.S. foreign policy. Ultimately, the work that Hoover and the FEC mission did in famine relief laid critical groundwork for the Marshall Plan that was directed to build long-term European stability through the capitalistic free market as a way of discouraging Communist expansion.

Truman's extension of mutual respect for Hoover as an ex-President emerged again in the efforts to reorganize the Executive Branch of the federal government. Again utilizing Hoover's government experience and demonstrated managerial capacities, the President referred to his assistance in producing the First Hoover Commission, refining several facets of the Executive Branch into a more efficient operation. Hoover's work in this regard extended into the presidency of Dwight D. Eisenhower, again demonstrating the additional recognition of his insights and experience. 
Even as political differences between Hoover and Truman had continued over approaches to foreign policy and issues that the Commission addressed, the common purpose on which they had founded their acquaintance remained into later years. Communication between the two ex-Presidents mainly revolved around mutual appreciation and Hoover's re-entry into government service through the FEC missions, which dwarfed the recognition of the more well-known events of the Hoover Commissions.

Historians can look at the coalition between Hoover and Truman and their shared goal of maintaining global stability and prosperity through American aid as one led by two figures with differing political stances towards the complex issues of long-term policy. This introduces the question as to how important personal interactions and relationships may be between leaders when generating or promoting national policies. In considering this, it is significant to remember that the FEC and its accomplishments in feeding millions of destitute people would not have happened, at least to the same degree of success or means, without the alliance and leadership of Hoover and Truman. At the same time, without the event of Truman's request to Hoover for advice and help in addressing the global famine problem, recognizing the ex-President's knowledge and abilities and asking him to return to undertake a major task of service, the friendship between the two Presidents may never have occurred. A similar question can be applied towards Truman's request of Hoover to undertake the leadership of the Hoover Commission, introducing the question of whether the future of national government would have followed a different path. 
When taking into account the underlying significance of the FEC mission and the Hoover and Truman friendship, it seems surprising that the secondary historical sources narrating the lives of both Presidents barely mention the event and the resulting friendship even less. This is even true of prominent Hoover biographers such as Richard Norton Smith's An Uncommon Man: The Triumph of Herbert Hoover (1984) or Joan Hoff Wilson's Herbert Hoover: Forgotten Progressive (1975). Nor do leading Truman biographers such as Melvyn P. Leffler in A Preponderance of Power: National Security, the Truman Administration, and the Cold War (1992) or even Robert H. Ferrell's Harry Truman: A Life (1994) discuss the series of events in detail. An exception is the compilation of documents and correspondence assembled in Herbert Hoover and Harry S. Truman: A Documentary History (1992) in which historians Timothy Walch and Dwight M. Miller provide commentary to both introduce and help explain the significance of relevant documents.

Did the popular stigma of Hoover as the President during the earliest years of the Great Depression remain into following decades, despite Truman's recognition and request for his help and leadership? In the same light, the postwar Truman Doctrine foreign policy, as well as Truman's responses to the Soviet threat and the permanence of the Marshall Plan receive far more attention in historical study.

Truman himself only provides a few sentences in his memoirs about the FEC and his exchanges with Hoover. Understandably, Hoover dedicates nearly an entire volume of his An American Epic series to chronicling the FEC missions, but nearly nothing about any bonds of friendship with Truman. The genuine thoughts of each, and regards for each 
other, surface in the subsequent correspondence of their later years, revealing the significance of their collaboration in national and world history, and for themselves.

The examination of these events helps to bring forth the manner in which both public figures have been assessed and evaluated, and how those personalities affected national and global futures. One sees, in the case of Hoover and Truman, how political differences and views can be overcome or even excused in order to pursue and accomplish a common purpose. The reality that a longtime discounted public figure can be utilized and affected by a national figure to attain positive results of both national, or American, and international influence and identity, is vital and can be discovered through an examination of the historical record. A survey of the sources points to the surprising discovery that through cooperation for similar goals, two antagonistic political personalities succeeded in developing a rare and distinct friendship.

Ultimately, it was not the final goal of either Herbert Hoover or Harry S. Truman to create or take credit for the legacies that applied directly to their own personal accomplishments within the work of the FEC missions or foreign policy. Likewise, their friendship was real, and indeed a positive biproduct of the work that they undertook as leaders. The culmination of their work and efforts in fighting postwar global famine and proliferating the principles that they believed in, nevertheless, proved helpful in sustaining an improved and secure world, even amid the developing tensions of the Cold War. 


\section{Bibliography}

\section{Primary Sources:}

Archival Materials:

Harry S. Truman Presidential Library and Museum Archives. Independence, Missouri.

Herbert Hoover Presidential Library and Museum Archives. West Branch, Iowa.

Register of the Citizens Committee for Reorganization of the Executive Branch Records. Online Archives of California. Stanford University, 2014.

Walch, Timothy and Dwight M. Miller ed. Herbert Hoover and Harry S. Truman: A Documentary History. Worland: High Plains Publishing, 1992.

Essays, Public Addresses, Reports, and Article Collections:

Hoover, Herbert. Addresses Upon the American Road: 1941-1945. New York: D. Van Nostrand Company, Inc., 1946.

-----. Addresses Upon the American Road: 1945-1948. New York: D. Van Nostrand Company, Inc., 1949.

-----. Addresses Upon the American Road: 1948-1950. Stanford: Stanford University Press, 1951.

-----. American Individualism. West Branch: Herbert Hoover Presidential Library Association, Inc., 1922.

------. An American Epic: The Guns Cease Killing and the Saving of Life from Famine Begins, $\quad$ 1939-1963, Volume IV. Chicago: Henry Regnery Company, 1964.

-----. Freedom Betrayed: Herbert Hoover's Secret History of the Second World War and Its Aftermath. Edited by George H. Nash. Stanford: Hoover Institution Press, 2011.

------. The Challenge to Liberty. West Branch: Herbert Hoover Presidential Library Association, Inc., 1934.

Pate, Maurice. "The Children Are Hungry." Report from the Famine Emergency Committee. U.S. Department of Agriculture, 1946.

The U.S. Constitution and Other Writings. San Diego: Canterbury Classics, 2017.

Government Records:

Congressional Quarterly. III. 1947.

The Hoover Commission Report on the Reorganization of the Executive Branch of the Government. New York: McGraw-Hill Book Company, Inc., 1949. 


\section{Memoirs:}

Gibson, Hugh. The Food Mission Diaries of Hugh Gibson (1946 and 1947). Hoover

Institution Archives. Www.digitalcollections.hoover.org.

Hoover, Herbert. The Memoirs of Herbert Hoover: Years of Adventure, 1874-1920. New York: The Macmillan Company, 1961.

Truman, Harry S. Memoirs by Harry S. Truman, Volume One: Year of Decisions. Garden City: Doubleday \& Company, 1955.

-----. Memoirs of Harry S. Truman, 1946-1952: Years of Trial and Hope, Volume II.

New York: Da Capo Press, Inc., 1956.

Newspapers:

The New York Times, 1949.

\section{Secondary Sources:}

Monographs:

Best, Gary Dean. Herbert Hoover: The Postpresidential Years, 1933-1964, Volume Two, Stanford: Hoover Institution Press, 1983.

Burner, David. Herbert Hoover: A Public Life. Alfred A. Knopf, 1979.

Cabanes, Bruno. The Great War and the Origins of Humanitarianism: 1918-1924. New York: Cambridge University Press, 2014.

Cullather, Nick. The Hungry World: America's Cold War Battle Against Poverty in Asia. Cambridge: Harvard University Press, 2010.

Ferrell, Robert H. Harry S. Truman: A Life. Columbia: University of Missouri Press, 1994.

Hamby, Alonzo L. Man of the People: A Life of Harry S. Truman. New York: Oxford University Press, 1995.

Leffler, Melvyn P. A Preponderance of Power: National Security, the Truman Administration and, the Cold War. Stanford: Stanford University Press, 1992.

------. The Specter of Communism: The United States and the Origins of the Cold War, 1917

1953. New York: Hill and Wang, 1994.

Lyons, Eugene. Our Unknown Ex-President: A Portrait of Herbert Hoover. Garden City: Doubleday \& Company, 1948.

Smith, Richard Norton. An Uncommon Man: The Triumph of Herbert Hoover. New York: Simon and Schuster, 1984. 
Williams, William Appleman. Some Presidents: Wilson to Nixon. New York: The New York Review of Books, 1972.

Wilson, Joan Hoff. Herbert Hoover: Forgotten Progressive. Prospect Heights: Waveland Press, 1975. 